\title{
The Biogeography of the Papio Baboons: A GIS-Based Analysis of Range Characteristics and Variability
}

\author{
Isabelle C. Winder \\ Department of Archaeology, University of York, York, UK
}

\begin{abstract}
Key Words
Papio · Biogeography · Geographical information systems · Environment · Range ·

Climate $\cdot$ Landscape $\cdot$ Vegetation
\end{abstract}

\begin{abstract}
The Papio baboons are known for their ecological flexibility and wide geographic ranges, as well as their uncertain taxonomy. There have, however, been few systematic comparisons of the environments occupied by the 6 major Papio species, and how differences in range conditions and variability might affect their evolutionary ecology remains unknown. This paper uses geographical information system techniques to explore the environmental associations of all 6 major species. It argues that despite some small differences in the average conditions encountered by each, it is in fact variation within individual ranges that is most apparent. In fact, the differences between the environments occupied by adjacent troops in well-known national parks may be as large or larger than the average differences in the ranges of different species, and this may have important implications for baboon biogeography.

(c) 2015 S. Karger AG, Basel
\end{abstract}

\section{Introduction}

The savannah baboons (genus Papio) form a cluster of 6 closely related allotaxa, classified either as separate species (e.g. Zinner et al. [2009, 2013]) or as subspecies of $P$. hamadryas. Their common names, used here, are the Guinea, hamadryas, olive, yellow, kinda and chacma baboons. All seem to be interfertile [Jolly et al., 1997; Arnold, 2009], and the Papio baboons as a whole are amongst the most successful African primates [Barrett and Henzi, 2008]. Their collective range spans most of subSaharan Africa - some 1,622 $\times 10^{4} \mathrm{~km}^{2}$ [Eeley and Foley, 1999] - and the south-west

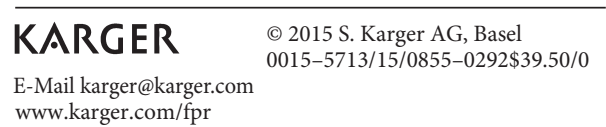

Isabelle C. Winde

Department of Archaeology, University of York King's Manor

York YO1 7EP (UK)

E-Mail isabelle.winder@york.ac.uk 
corner of the Arabian Peninsula, and includes habitats as varied as the semi-arid margins of the Sahara, the Namibian deserts, the evergreen tropical forests of the Congo basin and the grassy highlands of the Ethiopian Rift Valley. All 6 species are ecological generalists and opportunists, and many populations have adapted rapidly to living alongside humans [Warren, 2008].

The baboons' ecological flexibility and biogeographic spread makes them interesting in their own right, as well as a potential source of analogies for understanding early hominins [Jolly, 2001]. There are indications that different species may live in slightly different environments. Dunbar [1988], for example, suggested that the use of arid areas with low food densities might be responsible for the hamadryas baboon's unique social system, while the chacma baboon is also called the 'mountain' baboon for its use of the Drakensberg mountains [Henzi and Barrett, 2003]. Existing synthetic studies of individual baboon species' ranges and ecological niches, however, point to a complex relationship with the environment. The niche model of Stone et al. [2013] for the chacma baboon, for instance, suggested this species actually prefers cool, low-altitude habitats with moderate rainfall and may only use the marginal Drakensberg environments as a result of interactions with humans, and the study by Zinner et al. [2001] of hamadryas habitats in Eritrea found that this taxon does indeed use more arid environments than neighbouring olive baboons, but also occupies moist coastal lowlands and makes use of a wide range of vegetation types.

There seems to be considerable intraspecific variability in the habitats used by baboon troops [Kamilar, 2006; Kunz and Linsenmair, 2008], although there is also evidence for some overarching patterning in baboon-environment relationships at the genus scale. In particular, work on the relationships between activity budgets, climatic conditions and the demands of group-living has suggested that there are fundamental limits to the types of habitats Papio baboons can occupy [Dunbar, 1992; Bettridge et al., 2010; Bettridge and Dunbar, 2012], which likely apply across species, with some variation depending upon the ecology of the specific area considered. There may also be clinal patterns in baboon behavioural ecology [Kamilar, 2006]. Overall, however, these patterns encompass substantial within-genus variation and complexity, and understanding the evolution and significance of this variation remains a challenge. This is partly because much work on baboons to date has focused on the collection of long-term, detailed data for a small number of well-known troops. These troops may not be 'typical' of their taxa, and probably do not occupy the full range of environments Papio uses. They also tend to be fairly large and to occupy areas accessible to humans [Sharman and Dunbar, 1982].

Understanding the relationships between baboons and their habitats has obvious relevance for their conservation and for attempts to unpick the influences of humans on the ecosystems of sub-Saharan Africa. However, current approaches have their limitations. The selection of sites and troops for in-depth study is clearly nonrandom. Physical constraints on site access and study time are only part of the problem. The sociopolitical context affects the areas a researcher can safely visit, who can get research funding (and what for), and what can be done in the field. Anthropogenic impacts from the actions of researchers and neighbouring communities may disproportionately influence particular sites and the wider analyses which draw on them, and are not always easy to identify. And finally, the differences in the types and quality of data available for different troops and species may limit the possibilities for synthetic studies spanning multiple species. 
This paper, therefore, takes a different tack. Instead of drawing on point samples of each species' range, and integrating the detailed information available for each, it aims to explore the biogeography of Papio more holistically, using geographical information systems (GISs) to look at the full range of environments each species occupies. This approach has several advantages. Using a GIS allows for completely comparable analyses of each species' range, using the same environmental datasets. It permits work over a broader geographical area and mitigates the confounding effects of differences in site selection patterns, analytical methods and research strategies that would be encountered by attempts to integrate many small-scale site-specific studies. This means it is possible using GISs to conduct more in-depth, systematic analyses of environmental patterns and structures than would be possible using point samples. These advantages are, of course, countered by disadvantages: reliance on imperfect range maps, for example, and limited knowledge of what the presence of baboons in a broad area means in terms of the systematic use of habitats within it. However, the insights to be gained are potentially significant, and these techniques offer new opportunities to build upon existing understandings of baboon ecology. This paper will focus on 2 specific questions, both prominent in the existing literature (see above): (a) whether there is a 'typical' environment for each species and how they differ, and (b) how much environmental variability there is within each taxon's range and how it is organised, particularly with respect to the presence and scale of systematic patterning.

\section{Method}

\section{Materials}

Four sets of variables were chosen for this analysis: (1) data on the geographic ranges of the 6 baboon species; (2) climatic variables, known to be important to baboon socio-ecology [Hill et al., 2000; Hill and Dunbar, 2002]; (3) vegetation data, which may provide key information about the distribution of food, another important ecological factor [Dunbar, 1988], and (4) information on the physical landscape, an often overlooked but potentially important aspect of an organisms' evolutionary environment [Winder, 2012]. Digital maps of these data were obtained from various sources (table 1). The Arabian hamadryas baboons were excluded because the environmental data available for them were not comparable with those for their African relatives. Excluding these baboons is obviously not ideal, as it means not all environments used by baboons globally are included, but given that one aim of this paper is to consider more of the range of environments used by baboons than has hitherto been analysed, this is considered preferable to removing the species completely.

It is worth mentioning here that while maps of soils and geological units often resemble one another, and to a lesser extent patterns in vegetation (as can be seen in several of the figures presented later in this paper), they never correspond perfectly and may each have different, partially independent impacts on the animals living in the area. For example, while the most obvious effect of soil on animal distributions is indirect - via the soil's influence on the types of vegetation an area can support - there can also be more direct edaphic influences. Even where several different soils might support structurally similar woodlands, there may be differences in the nutrient and water contents of plants growing in different soils that can be significant for animals' growth, development and health [Sturdy et al., 1997]. Similarly, different geological units can influence edaphics, soil structures, water retention and surface morphology and change in ways that can affect animals independently of changes induced by, for example, tectonic activity, changing global circulation patterns and other factors influencing landscape and ecology. It is difficult to understand exactly how the different variables mapped in this work interact, as their interactions are part of a non-linear, complex Earth system [Winder, 2012], but it is clear that each may am- 
Table 1. The variables chosen to analyse the environments of the 6 Papio species and the sources of the data used

\begin{tabular}{|c|c|c|}
\hline Data set & Variable & Source \\
\hline $\begin{array}{l}\text { Species } \\
\text { distributions }\end{array}$ & $\begin{array}{l}\text { Ranges of the olive, yellow, kinda, hamadryas, } \\
\text { Guinea and chacma baboons }\end{array}$ & $\begin{array}{l}\text { The IUCN Red List } \\
\text { databank [IUCN, 2012] }\end{array}$ \\
\hline Climate & $\begin{array}{l}\text { Annual mean temperature }\left({ }^{\circ} \mathrm{C}\right) \\
\text { Annual mean rainfall values (mm) } \\
\text { Rainfall seasonality (the coefficient of variation on } \\
\text { annual rainfall; in arbitrary units from } 0 \text { to } 300) \\
\text { Temperature seasonality (the standard deviation of } \\
\text { annual temperature multiplied by } 100 \text {; in arbitrary } \\
\text { units from } 0 \text { to } 225,000)\end{array}$ & $\begin{array}{l}\text { WorldClim database } \\
\text { [Hijmans et al., 2005] }\end{array}$ \\
\hline Vegetation & $\begin{array}{l}\text { Vegetation map (re-classified into 'open', } \\
\text { 'semi-open', 'closed', 'aquatic' and 'arid/semi-arid' } \\
\text { vegetation) }\end{array}$ & $\begin{array}{l}\text { The Vegetation Map of } \\
\text { Africa [White, 1983], } \\
\text { digitised as part of the } \\
\text { creation of the 'Useful } \\
\text { Tree Species for Africa' } \\
\text { tool [Kindt et al., 2011] }\end{array}$ \\
\hline \multirow[t]{3}{*}{$\begin{array}{l}\text { Landscape } \\
\text { (terrain and } \\
\text { spatial } \\
\text { patterning) }\end{array}$} & $\begin{array}{l}\text { Altitude (m) } \\
\text { Terrain roughness - a measure of the variability in } \\
\text { slope orientations (calculated as the slope of the } \\
\text { slope using the ArcGIS' 'slope' function, and given } \\
\text { as a range from } 0 \text { to } 1 \text { ) }\end{array}$ & $\begin{array}{l}\text { STRM30 (v2) data } \\
\text { [Farr et al., 2007] }\end{array}$ \\
\hline & Surface geology & USGS [2000] \\
\hline & $\begin{array}{l}\text { Surface soil types (classified as in the Harmonised } \\
\text { World Soil Database) }\end{array}$ & $\begin{array}{l}\text { FAO/IIASA/ISS-CAS/ } \\
\text { JRC [2009] }\end{array}$ \\
\hline
\end{tabular}

plify or modify changes to others in a complex fashion or have semi-independent effects on the biosphere. For these reasons, this paper includes maps of all the variables listed in table 1, even where they might initially seem to show similar patterns.

Data on the 6 species' distributions were obtained from the IUCN Red List databank [2012] and subjected to sensitivity analyses which used comparisons with maps from the literature to identify areas of uncertainty and check the digital range boundaries (table 2). The IUCN's range maps are based on those presented in Sechrest [2003] and other major sources - notably Kingdon [1997] for African mammals - modified taxon by taxon to take account of other sightings, localities and descriptions of ranges given in the ecological literature [IUCN, 2013]. A full list of sources used is given under each species' entry in the database, but this does not of course include every paper yet published on an individual species, hence the need for sensitivity analysis using up-to-date specialist papers. As table 2 shows, the different sources used here broadly agree. The biggest uncertainties relate to (a) the status of the kinda baboon (not classified separately by all authors) and (b) the presence of chacma baboons in south-west Botswana and east Namibia, included within their range by Groves [2001] and Newman et al. [2004] but excluded by others. This area corresponds to the 'gap' in the middle of the chacma baboon range (visible on fig. 1, which shows the IUCN data). These IUCN maps, this analysis suggests, match well with other key sources and exclude the area where occupation is most uncertain. It still remains unclear at this time whether the baboon ranges, so defined, are fully occupied or whether there are 'gaps' in the distributions of troops. Certainly baboon population density varies spatially [Winder, 2012], 
Table 2. Descriptions of the ranges each of the 6 major Papio species, as given in the IUCN Red List database and key papers, showing the broad similarities between them and identifying key areas of difference

\begin{tabular}{|c|c|c|c|c|c|c|}
\hline Source & $\begin{array}{l}\text { Guinea } \\
\text { baboon }\end{array}$ & $\begin{array}{l}\text { Hamadryas } \\
\text { baboon }\end{array}$ & $\begin{array}{l}\text { Olive } \\
\text { baboon }\end{array}$ & $\begin{array}{l}\text { Yellow } \\
\text { baboon }\end{array}$ & $\begin{array}{l}\text { Kinda } \\
\text { baboon }\end{array}$ & $\begin{array}{l}\text { Chacma } \\
\text { baboon }\end{array}$ \\
\hline $\begin{array}{l}\text { IUCN } \\
\text { Red List } \\
\text { database }\end{array}$ & $\begin{array}{l}\text { From Guinea, } \\
\text { Guinea-Bissau, } \\
\text { Senegal and the } \\
\text { Gambia into } \\
\text { W Mali and } \\
\text { Mauretania and } \\
\text { a sliver of NW } \\
\text { Sierra Leone }\end{array}$ & $\begin{array}{l}\text { NE Ethiopia, } \\
\text { extending into } \\
\text { Eritrea, } \\
\text { Djibouti, NW } \\
\text { Somalia and a } \\
\text { small part of } \\
\text { E Sudan }\end{array}$ & $\begin{array}{l}\text { From Mali and Guinea } \\
\text { in the W across to SW } \\
\text { Ethiopia and S into the } \\
\text { Democratic Republic of } \\
\text { the Congo, Kenya and } \\
\text { NW Tanzania, plus two } \\
\text { outposts in Chad and } \\
\text { Niger }\end{array}$ & $\begin{array}{l}\mathrm{N} \\
\text { Mozambique, } \\
\text { Malawi and } \\
\text { Tanzania, and } \\
\text { N into SE } \\
\text { Kenya and } \\
\text { S Somalia }\end{array}$ & $\begin{array}{l}\text { S Democratic } \\
\text { Republic of the } \\
\text { Congo, Zambia } \\
\text { and N Angola, } \\
\text { extending S into } \\
\text { a small part of } \\
\text { W Mozambique }\end{array}$ & $\begin{array}{l}\text { S Zambia, } \\
\text { Zimbabwe, } \\
\text { NE Botswana, } \\
\text { S Mozambique, } \\
\text { South Africa, } \\
\text { Lesotho, Swaziland } \\
\text { and Namibia, } \\
\text { extending N into } \\
\text { S Angola }\end{array}$ \\
\hline $\begin{array}{l}\text { Groves } \\
\text { [2001] }\end{array}$ & $\begin{array}{l}\text { From Guinea, } \\
\text { Guinea-Bissau } \\
\text { and Senegal and } \\
\text { an unknown } \\
\text { distance into } \\
\text { Mauretania and } \\
\text { Mali }\end{array}$ & $\begin{array}{l}\text { The arid zone of } \\
\text { the N Ethiopian } \\
\text { lowlands, E into } \\
\text { N Somalia and } \\
\text { W into the Red } \\
\text { Sea Hills of the } \\
\text { Sudan }\end{array}$ & $\begin{array}{l}\text { From Mali E to the } \\
\text { Ethiopian Highlands and } \\
\text { SE into Kenya and } \\
\text { NW Tanzania }\end{array}$ & $\begin{array}{l}\text { S Somalia, } \\
\text { SE Kenya, } \\
\text { Malawi, N } \\
\text { Mozambique } \\
\text { and most of } \\
\text { Tanzania }\end{array}$ & $\begin{array}{l}\text { Zambia, Angola } \\
\text { and the } \\
\text { Democratic } \\
\text { Republic of the } \\
\text { Congo } \\
\text { (described in } \\
\text { less detail as a } \\
\text { species of yellow } \\
\text { baboon) }\end{array}$ & $\begin{array}{l}\text { S of the Zambezi } \\
\text { river (Zimbabwe, } \\
\text { S Mozambique, } \\
\text { South Africa, } \\
\text { Lesotho, Botswana } \\
\text { and Namibia), } \\
\text { reaching N into } \\
\text { S Angola and } \\
\text { SW Zambia }\end{array}$ \\
\hline $\begin{array}{l}\text { Newman } \\
\text { et al. [2004]; } \\
\text { re-used, } \\
\text { with very } \\
\text { slight modi- } \\
\text { fications, } \\
\text { by Kamilar } \\
\text { [2006] }\end{array}$ & $\begin{array}{l}\text { W Guinea, } \\
\text { Guinea-Bissau, } \\
\text { Senegal, the } \\
\text { Gambia and } \\
\text { parts of W Mali } \\
\text { and Mauretania }\end{array}$ & $\begin{array}{l}\text { NE Ethiopia, } \\
\text { Djibouti and } \\
\text { N Somalia }\end{array}$ & $\begin{array}{l}\text { From Guinea, Sierra } \\
\text { Leone and Mali in the W } \\
\text { through to W Ethiopia } \\
\text { and S into the } \\
\text { Democratic Republic of } \\
\text { the Congo, W Kenya and } \\
\text { NW Tanzania, plus two } \\
\text { outposts in Chad and } \\
\text { Niger }\end{array}$ & \multicolumn{2}{|c|}{$\begin{array}{l}\text { Yellow and kinda baboons are } \\
\text { lumped and depicted as ranging } \\
\text { from } N \text { Angola in the } W \text { through } \\
\text { most of Zambia, the } S \text { of the } \\
\text { Democratic Republic of the } \\
\text { Congo, N Mozambique/Malawi } \\
\text { and N into Tanzania, SE Kenya } \\
\text { and S Somalia }\end{array}$} & $\begin{array}{l}\text { S of the Zambezi } \\
\text { river (defined as } \\
\text { above and } \\
\text { including Botswana } \\
\text { and Namibia) and } \\
\text { northwards into } \\
\text { S Angola and } \\
\text { SW Zambia }\end{array}$ \\
\hline $\begin{array}{l}\text { Burrell } \\
\text { et al. [2009] }\end{array}$ & $\begin{array}{l}\text { W Guinea, } \\
\text { Guinea-Bissau, } \\
\text { Senegal and the } \\
\text { Gambia, and } \\
\text { small areas of } \\
\text { Mali and } \\
\text { Mauretania }\end{array}$ & $\begin{array}{l}\text { Much of } \\
\text { Ethiopia, parts } \\
\text { of E Eritrea, } \\
\text { Djibouti and } \\
\text { N Somalia }\end{array}$ & $\begin{array}{l}\text { From Guinea, Mali and } \\
\text { Sierra Leone in the W to } \\
\text { W Ethiopia and Eritrea } \\
\text { in the E, and S as far as } \\
\text { W Kenya, NW Tanzania } \\
\text { and NE Democratic } \\
\text { Republic of the Congo, } \\
\text { with outposts in Niger } \\
\text { and Chad }\end{array}$ & \multicolumn{2}{|c|}{$\begin{array}{l}\text { Yellow and kinda baboons are } \\
\text { again grouped together, with a } \\
\text { range from N Angola in the } \\
\text { W through the S Democratic } \\
\text { Republic of the Congo, Zambia, } \\
\text { N Mozambique and Malawi, } \\
\text { Tanzania, SE Kenya and S Somalia }\end{array}$} & $\begin{array}{l}\text { S of the Zambezi } \\
\text { river (defined as } \\
\text { above), with the } \\
\text { exception of parts of } \\
W \text { Botswana and } \\
\text { E Namibia, and N } \\
\text { into S Angola and } \\
\text { SW Zambia }\end{array}$ \\
\hline
\end{tabular}

These areas of difference primarily affect the chacma baboon range in Botswana and Namibia, and the appropriate parts of each range description are emphasised in italics. The kinda baboon range was described by Jolly et al. [2011], the first to recognise its distinctive morphology and genetics, as taking in the extreme SW of Tanzania, Zambia, the S Democratic Republic of the Congo and most of Angola, in keeping with the IUCN maps.

but as our knowledge of small-scale baboon ecology comes from a few in-depth studies of specific regions, we cannot yet take this into account in large-scale analyses. The IUCN maps thus represent a reasonable starting point, and I propose that their use can be treated as a baseline assumption which, by enabling us to carry out initial analyses, will ultimately allow us to identify areas in need of refinement or of particular interest for further research. For now, excluding only those areas where baboon presence is the subject of significant disagreement is a compromise based on the fact that restricting analyses to areas we are absolutely certain of is likely to be counterproductive in analyses aimed at summarising ranges.

A further challenge to biogeographic studies using range maps rather than point data, as mentioned above, comes from the fact that we lack detailed knowledge of the distribution of baboons within their ranges. In an attempt to begin to tackle this, and to further explore small-scale variability in baboon environments, the digital maps presented are ultimately discussed in the context of 3 case studies from the primatological literature. These focus on differences in the ecologies of baboons in the national parks at De Hoop [Hill, 1999], Amboseli [Altmann and Alt- 


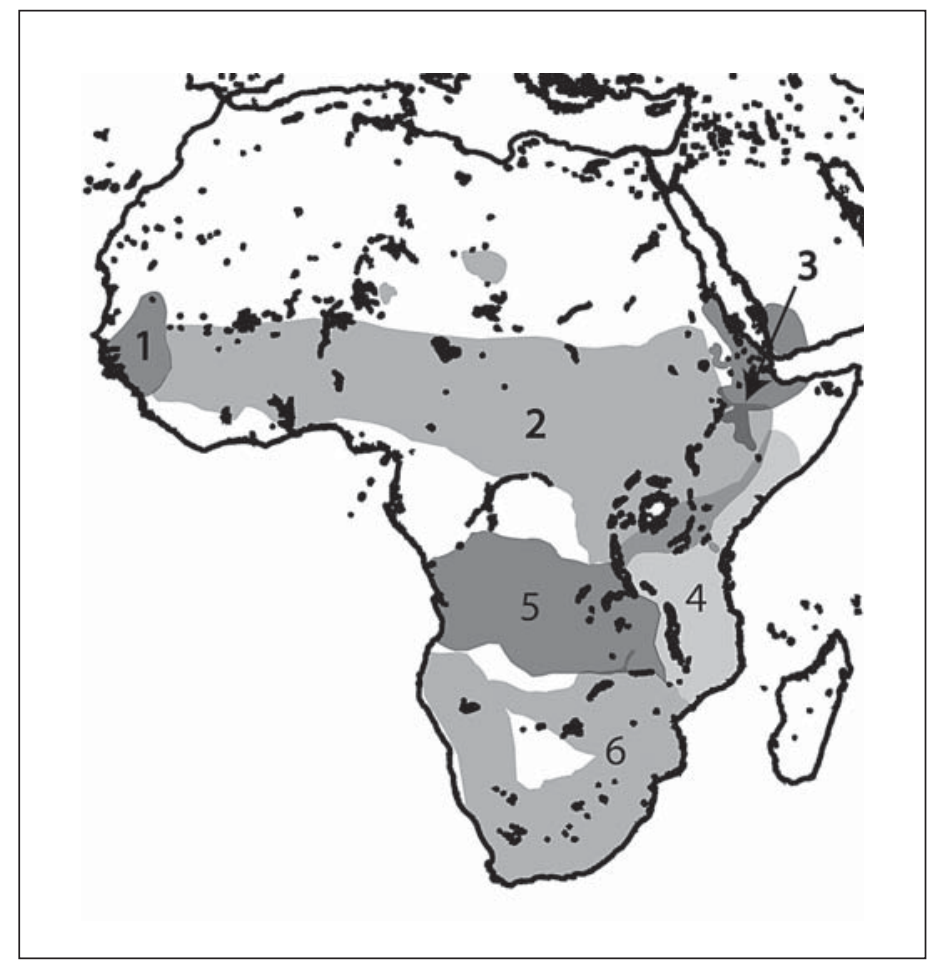

Fig. 1. Map of Africa and the ranges of the 6 baboon species from IUCN data. Figures 2-7, which show the environments in each range, show only the relevant areas, so this map is provided for comparative purposes. Ranges are numbered as follows: (1) Guinea, (2) olive, (3) hamadryas, (4) yellow, (5) kinda and (6) chacma baboon.

mann, 1970; Altmann et al., 1981; Altmann and Muruthi, 1988; Altmann et al., 2002] and Gashaka Gumti [Warren, 2008; Ross et al., 2011; Warren et al., 2011]. These 3 case studies were chosen for their high-quality data, which allowed for comparisons between the environments of adjacent troops at De Hoop and Gashaka, and of one troop over a prolonged period of environmental change at Amboseli. These 3 samples are also environmentally diverse: they fall into different climatic regimes and different ecoregions, allowing for an exploration of the role(s) of small-scale variability under different overall conditions. The Gashaka baboons occupy an area of West African rain forest, though they mainly occupy the forest-grassland transition zone [Higham et al., 2009], the De Hoop baboons live in an area dominated by coastal fynbos, with a highly seasonal climate [Hill et al., 2003; Hill, 2006] and the Amboseli group uses savannah contexts [Altmann et al., 1985].

Methods

Digital data sets were opened in Global Mapper 12.0, used to mosaic SRTM30 tiles together, to impose a uniform WGS 84 projection and to cut global data sets into smaller chunks for import into ArcGIS 10.0. Six ArcGIS projects - one per species - were then opened, and the data imported into a common geodatabase. Within each, maps were trimmed to the shape of the species' range using the 'Clip' tools, and raster data sets were passed through the 'Set Null' tool to ensure that points that fell in oceans or lakes, which ArcGIS arbitrarily assigns an extreme value of $\pm 32,767$ on importation, would be properly recognised as null. 
Table 3. Details of the environmental components each continuous variable was divided into for multiple correspondence analysis (table 1 defines the units for each variable)

\begin{tabular}{|c|c|c|}
\hline Variable & $\begin{array}{l}\text { Components } \\
\text { created, } \mathrm{n}\end{array}$ & Component labels and values (in brackets) \\
\hline Altitude & 5 & $\begin{array}{l}\text { Low }(-154 \text { to } 1,029 \mathrm{~m}) \text {, low-medium }(1,030-2,212 \mathrm{~m}) \text {, } \\
\text { medium }(2,213-3,395 \mathrm{~m}) \text {, medium-high }(3,396-4,578 \mathrm{~m}) \text { and } \\
\text { high }(4,579-5,761 \mathrm{~m})\end{array}$ \\
\hline Roughness & 3 & $\begin{array}{l}\text { Low (scores in the range } 0-0.298 \text { units), medium }(0.299-0.596 \\
\text { units) and high ( } 0.597-0.895 \text { units) }\end{array}$ \\
\hline $\begin{array}{l}\text { Annual mean } \\
\text { temperature }\end{array}$ & 5 & $\begin{array}{l}\text { Low }\left(-5 \text { to } 2.4^{\circ} \mathrm{C}\right) \text {, low-medium }\left(2.5-9.8^{\circ} \mathrm{C}\right) \text {, medium }(9.9- \\
\left.17.2^{\circ} \mathrm{C}\right) \text {, medium-high }\left(17.3-24.6^{\circ} \mathrm{C}\right) \text { and high }\left(24.7-32^{\circ} \mathrm{C}\right)\end{array}$ \\
\hline Rainfall & 4 & $\begin{array}{l}\text { Low (3-956 mm/year), low-medium ( } 957-1,909 \mathrm{~mm} / \text { year }) \text {, } \\
\text { medium-high }(1,910-2,862 \mathrm{~mm} / \text { year }) \text { and high }(2,863-3,815 \\
\mathrm{mm} / \text { year })\end{array}$ \\
\hline $\begin{array}{l}\text { Temperature } \\
\text { seasonality }\end{array}$ & 5 & $\begin{array}{l}\text { Low }(71-1,361 \text { units }), \text { low-medium }(1,362-2,651 \text { units }) \\
\text { medium }(2,652-3,941 \text { units }) \text {, medium-high }(3,942-5,231 \\
\text { units) and high }(5,232-6,520 \text { units })\end{array}$ \\
\hline $\begin{array}{l}\text { Rainfall } \\
\text { seasonality }\end{array}$ & 4 & $\begin{array}{l}\text { Low ( } 20-72 \text { units), low-medium ( } 73-125 \text { units), medium- } \\
\text { high ( } 126-177 \text { units) and high ( } 178-229 \text { units) }\end{array}$ \\
\hline
\end{tabular}

The vegetation map, which originally divided habitats into $\sim 20$ categories, was redrawn to display 5 major vegetation types, namely open vegetation (including areas originally called grassland or edaphic grassland mosaics), semi-open vegetation (alimontane vegetation, bushlands and thickets, bushland and thicket mosaics, woodlands and woodland mosaics), closed vegetation (forests, forest transitions and forest mosaics), aquatic vegetation (halophytic plants, herbaceous freshwater swamp and aquatic vegetation, mangroves and areas of open water) and arid/semiarid vegetation zones (desert or semi-desert vegetation) using the 'Merge' tool. This was done for 2 reasons. First, reducing the number of categories substantially simplified subsequent analyses. And second, the changing spatiotemporal configuration of African habitats since the production of the vegetation map of Africa [White, 1983], and the uncertain ecological effects of living in slightly different habitats - a 'woodland' as opposed to a 'woodland mosaic', for example - mean that it is likely to be difficult to convert knowledge on the more detailed configuration of vegetation types into biogeographically meaningful data anyway.

Finally, maps of terrain roughness were extrapolated from the SRTM30 altitude data. In this paper, roughness is defined as the variability in surface heights and orientations on a terrain (with a low roughness value, near 0 , indicating a smooth, level surface and a high value of close to 1 a surface comprising lots of blocks of different heights and orientations). Terrain roughness can be measured in various ways, the simplest of which is by making a slope map - so that each cell contains not an altitude value but a value representing how different that altitude is from those of the surrounding cells - and then taking the slopes of the slope map, to generate a map of the variability in slope values. The ArcGIS' 'Slope' tool was used to do this, with appropriate Z values (parameters representing the ratio between altitude in metres and the size of cells, measured in degrees) set using the online ArcGIS resources.

Mean, minimum and maximum values for the continuous variables (altitude, terrain roughness, temperature, rainfall, temperature seasonality and rainfall seasonality, measured as described in table 1) were extracted using the ArcGIS' 'Band Collection Statistics' tool. Descriptions of the categorical variables' distributions (vegetation, geology and soils) were compiled manu- 
Table 4. Summaries of the continuous environmental variability in each baboon species' range

\begin{tabular}{|c|c|c|c|c|c|c|c|}
\hline Variable & & $\begin{array}{l}\text { Guinea } \\
\text { baboon }\end{array}$ & $\begin{array}{l}\text { Hamadryas } \\
\text { baboon }\end{array}$ & $\begin{array}{l}\text { Olive } \\
\text { baboon }\end{array}$ & $\begin{array}{l}\text { Yellow } \\
\text { baboon }\end{array}$ & $\begin{array}{l}\text { Kinda } \\
\text { baboon }\end{array}$ & $\begin{array}{l}\text { Chacma } \\
\text { baboon }\end{array}$ \\
\hline \multirow{4}{*}{ Altitude, m } & mean & 173.8 & $1,010.3$ & 651.7 & 734.5 & 978.8 & 984.4 \\
\hline & minimum & 1.0 & -154.0 & -3.0 & 0.0 & 0.0 & \\
\hline & maximum & $1,481.0$ & $4,385.0$ & $5,761.0$ & $5,746.0$ & $2,478.0$ & $3,377.0$ \\
\hline & range & 1,480 & 4,539 & 5,764 & 5,746 & 2,478 & 3,376 \\
\hline \multirow{4}{*}{$\begin{array}{l}\text { Roughness } \\
\text { (scored from } \\
0 \text { to } 1 \text { ) }\end{array}$} & mean & 0.017 & 0.048 & 0.017 & 0.021 & 0.021 & 0.026 \\
\hline & minimum & 0.0 & 0.0 & 0.0 & 0.0 & 0.0 & \\
\hline & maximum & 0.477 & 0.842 & 0.829 & 0.724 & 0.544 & 0.895 \\
\hline & range & 0.477 & 0.842 & 0.829 & 0.724 & 0.544 & 0.895 \\
\hline \multirow{4}{*}{$\begin{array}{l}\text { Annual mean } \\
\text { temperature, } \\
{ }^{\circ} \mathrm{C}\end{array}$} & mean & 27.6 & 24.2 & 25.4 & 23.7 & 22.2 & 19.5 \\
\hline & minimum & 20.0 & 4.2 & -5.0 & -5.0 & 16.2 & 4.1 \\
\hline & maximum & 30.5 & 32.0 & 30.7 & 30.7 & 28.3 & 26.9 \\
\hline & range & 10.5 & 27.8 & 35.7 & 35.7 & 12.1 & 22.8 \\
\hline \multirow{4}{*}{$\begin{array}{l}\text { Annual mean } \\
\text { rainfall, mm }\end{array}$} & mean & $1,050.6$ & 462.6 & 969.8 & 899.2 & $1,228.3$ & 513.4 \\
\hline & minimum & 118.0 & 10.0 & 3.0 & 244.0 & 76.0 & 26.0 \\
\hline & maximum & $3,815.0$ & $1,583.0$ & $3,040.0$ & $2,611.0$ & $1,814.0$ & $2,485.0$ \\
\hline & range & 3,697 & 1,573 & 3,037 & 2,367 & 1,738 & 2,459 \\
\hline \multirow{4}{*}{$\begin{array}{l}\text { Temperature } \\
\text { seasonality, } \\
\text { arbitrary units }\end{array}$} & mean & $2,375.0$ & $2,131.8$ & $1,631.2$ & $1,481.2$ & $1,497.1$ & $3,728.4$ \\
\hline & minimum & 788.0 & 583.0 & 71.0 & 276.0 & 228.0 & $1,153.0$ \\
\hline & maximum & $4,654.0$ & $4,479.0$ & $6,520.0$ & $3,018.0$ & $3,423.0$ & $6,642.0$ \\
\hline & range & 3,866 & 3,896 & 6,449 & 2,742 & 3,195 & 5,489 \\
\hline \multirow{4}{*}{$\begin{array}{l}\text { Rainfall } \\
\text { seasonality, } \\
\text { arbitrary units }\end{array}$} & mean & 128.4 & 75.7 & 94.4 & 94.4 & 86.3 & 84.7 \\
\hline & minimum & 83.0 & 32.0 & 20.0 & 27.0 & 40.0 & 10.0 \\
\hline & maximum & 160.0 & 139.0 & 229.0 & 164.0 & 133.0 & 139.0 \\
\hline & range & 77 & 107 & 209 & 137 & 93 & 129 \\
\hline
\end{tabular}

Grey shading highlights the highest and lowest means for each variable.

ally using the 'Identify' tool. Range areas were found using the ArcGIS 'Calculate Geometry' tool after reprojecting all maps into an equal-area format (the preset Africa Albers Equal-Area Conic projection). These were used with each range's minimum and maximum values for the continuous variables to calculate Pearson's correlations between area and internal environmental variability in Excel. Figures were made in Adobe Illustrator 5.5 with MAPublisher 12.0.

Analyses of numerical correlations only work for ordinal or continuous data (that is, there needs to be a meaningful relationship between adjacently numbered categories in a variable), but the soil, vegetation and geology maps used here comprise nominal data. To explore the environmental structures of each baboon range further, using all the mapped variables, a multivariate statistical technique capable of analysing nominal data was therefore required. I chose multiple correspondence analysis (MCA). MCA is a technique for visualising large data sets on a few axes, calculated to explain as much as possible of the total variation, and is comparable to principal components analyses for continuous data. MCA works on presence-absence data, which required that each variable be converted into a set of environmental components (e.g. 'open vegetation' or 'low altitude'), each of which could be scored as present or absent for each point on the landscape sampled. 
Table 5. Summaries of the discontinuous variation in each baboon species' range

\begin{tabular}{|c|c|c|c|}
\hline & Vegetation & Surficial geology & Soil type \\
\hline $\begin{array}{l}\text { Guinea baboon } \\
\text { (compare fig. 2) }\end{array}$ & $\begin{array}{l}\text { Closed, semi-open, } \\
\text { arid/semi-arid and } \\
\text { aquatic vegetation } \\
\text { represented; dominated } \\
\text { by semi-open contexts }\end{array}$ & $\begin{array}{l}\text { Broadly Tertiary to the west } \\
\text { and Precambrian (with } \\
\text { inclusions) to the east, with a } \\
\text { major anomaly in west } \\
\text { Guinea }\end{array}$ & $\begin{array}{l}\text { Complex and not clearly } \\
\text { patterned, except for a } \\
\text { large patch of leptosol } \\
\text { centred on the geological } \\
\text { anomaly in west Guinea }\end{array}$ \\
\hline $\begin{array}{l}\text { Hamadryas } \\
\text { baboon } \\
\text { (compare fig. } 3 \text { ) }\end{array}$ & $\begin{array}{l}\text { Closed, semi-open, arid/ } \\
\text { semi-arid and aquatic } \\
\text { vegetation represented; } \\
\text { arid/semi-arid contexts } \\
\text { dominate }\end{array}$ & $\begin{array}{l}\text { Very complex and patchy, } \\
\text { especially near the coast }\end{array}$ & $\begin{array}{l}\text { Randomly distributed } \\
\text { pockets of various } \\
\text { soils within a matrix of } \\
\text { leptosol }\end{array}$ \\
\hline $\begin{array}{l}\text { Olive baboon } \\
\text { (compare fig. } 4 \text { ) }\end{array}$ & $\begin{array}{l}\text { All vegetation types } \\
\text { (open, semi-open, closed, } \\
\text { aquatic and arid/semi- } \\
\text { arid) represented; } \\
\text { dominated by semi-open } \\
\text { contexts }\end{array}$ & $\begin{array}{l}\text { Highly complex and variable } \\
\text { in age }\end{array}$ & $\begin{array}{l}\text { Highly complex and } \\
\text { variable }\end{array}$ \\
\hline $\begin{array}{l}\text { Yellow baboon } \\
\text { (compare fig. 5) }\end{array}$ & $\begin{array}{l}\text { All vegetation types } \\
\text { represented; dominated } \\
\text { by semi-open contexts }\end{array}$ & $\begin{array}{l}\text { Complex, but with a basic } \\
\text { matrix of Precambrian rock } \\
\text { with inclusions of other ages }\end{array}$ & $\begin{array}{l}\text { Equally highly complex } \\
\text { and variable }\end{array}$ \\
\hline $\begin{array}{l}\text { Kinda baboon } \\
\text { (compare fig. 6) }\end{array}$ & $\begin{array}{l}\text { All vegetation types } \\
\text { represented; dominated } \\
\text { by semi-open and closed } \\
\text { contexts }\end{array}$ & $\begin{array}{l}\text { Broadly organised as a north- } \\
\text { south ridge of Cenozoic rock, } \\
\text { with inclusions of Quaternary } \\
\text { and other types, in a matrix } \\
\text { of Precambrian rock }\end{array}$ & $\begin{array}{l}\text { Similar to the geology } \\
\text { map, with arenosol over } \\
\text { the ridge and ferralsol } \\
\text { over the Precambrian } \\
\text { matrix }\end{array}$ \\
\hline $\begin{array}{l}\text { Chacma baboon } \\
\text { (compare fig. } 7 \text { ) }\end{array}$ & $\begin{array}{l}\text { All vegetation types } \\
\text { represented; dominated } \\
\text { by semi-open contexts }\end{array}$ & $\begin{array}{l}\text { A Precambrian base, with } \\
\text { three anomalies: a large } \\
\text { Cenozoic mass in Botswana, } \\
\text { sizeable Tertiary and } \\
\text { Pleistocene coastal deposits } \\
\text { and a block of Triassic/ } \\
\text { Permian and Mesozoic } \\
\text { igneous rocks in South Africa }\end{array}$ & $\begin{array}{l}\text { Largely randomly } \\
\text { distributed and variable, } \\
\text { though with extensive } \\
\text { arenosol deposits over the } \\
\text { Cenozoic block and areas } \\
\text { of solonetz soils on the } \\
\text { coastal plains }\end{array}$ \\
\hline
\end{tabular}

To get data into an appropriate format for sampling, the two vector maps were converted to rasters using the ArcGIS' 'Polygon to Raster' tool, set so that cells containing more than one value took the one that covered more of their area. The 'Sample' tool was then used to extract data on points across each species' range, with the cells of the lowest resolution raster (the soil map) used to define those points. The resulting data were exported to Excel, and points with a null value (produced where raster edges did not precisely align) or which were classified as 'sea' or 'water' were removed. Excel's 'IF' functions were then used to reclassify each of the 9 environmental variables as a set of environmental components scored as present or absent. For categorical variables, this meant creating the same number of new variables as there were categories and using if-then statements to extract the correct pattern of one and zeros. For continuous variables, there was an extra step - the definition of categories. This was done by taking the full range of each variable across the 6 data sets and dividing it into 3-5 categories, depending upon the scale 
of the variation present (see table 3 for details). The resulting data set comprised 101 environmental components in total, including 26 derived from the continuous variables, 5 vegetation components (open, semi-open, closed, aquatic and arid/semi-arid), 30 soil types and 40 geological units. Both of these latter sets were sampled directly using the categories given on the original maps. MCAs were conducted using the PAST package [Hammer et al., 2001].

The small-scale case studies, used to explore within-range variation in greater depth, made use of descriptive data from the literature as the large-scale maps lacked the resolution for use at this scale. These data comprised average values or ranges for conditions in each troop's range, and were used qualitatively, so no further statistical methods were necessary.

\section{Results}

Average Conditions for Each Species

Tables 4 and 5 summarise the environmental conditions in each of the 6 Papio species' ranges, the former focusing on the continuous variables and the latter the categorical ones. As these tables show, there do seem to be some differences in the broad environments used by each species. Although these differences are small, they are discussed in some detail here, first because in the interests of a complete analysis they cannot be excluded, and second because their nature supports the suggestion that there is no clear niche separation between the 6 major baboon allotaxa, which has implications for our understanding of their environments and evolution as well as their biogeography.

The Guinea baboon's range (fig. 2) spans the lowest altitude, smoothest terrain (mean altitude: $173.8 \mathrm{~m}$, mean roughness score: 0.017 units) of any species. It has the highest average temperature $\left(27.6^{\circ} \mathrm{C}\right)$, and is quite seasonal, with a mean rainfall seasonality of 128.4 units (the highest of the 6 ranges) and a mean temperature seasonality of 2,375 (the second highest). While rainfall in this range is intermediate (on average $1,050.6 \mathrm{~mm} /$ year), it has the widest range of rainfall values of any species. For other variables, however, this species seems to occupy a restricted set of conditions, with the narrowest range of values of any species for all of the continuous variables save annual rainfall and temperature seasonality. It is also 1 of only 2 species not to occupy regions of all 5 major vegetation types, and the range has relatively simple geological and soil maps.

The hamadryas range (fig. 3) is distinctive in occupying, on average, the highest altitudes, the roughest terrain and the lowest rainfall of any Papio species (mean values of $1,010.3 \mathrm{~m}, 0.048$ units and $462.6 \mathrm{~mm} /$ year, respectively). Its temperatures are intermediate $\left(24.2^{\circ} \mathrm{C}\right.$ on average) and moderately seasonal (average temperature seasonality: $2,131.8$ units), while rainfall is not just absolutely low but the least seasonal of any baboon range (average rainfall seasonality: 75.7 units). The hamadryas baboon ranges over very variable soils and geologies, and its range is the only to be composed in significant proportion of arid/semi-arid vegetation. Overall, despite being relatively small in area, the hamadryas range typically spans the second or third largest range of values for each continuous variable studied.

The olive baboon range (fig. 4) spans a wide range of conditions for nearly all variables. It has the widest range of values for altitude (from -3 to $5,761 \mathrm{~m}$ ) and both measures of seasonality (71-6,520 units of temperature seasonality and 20-229 units of rainfall seasonality). It shares the widest range of temperature scores (from -5 to $30.7^{\circ} \mathrm{C}$ ) with the yellow baboon range, and is thus 1 of only 2 taxa to apparently use areas with mean annual temperatures below zero. The data we currently have avail- 


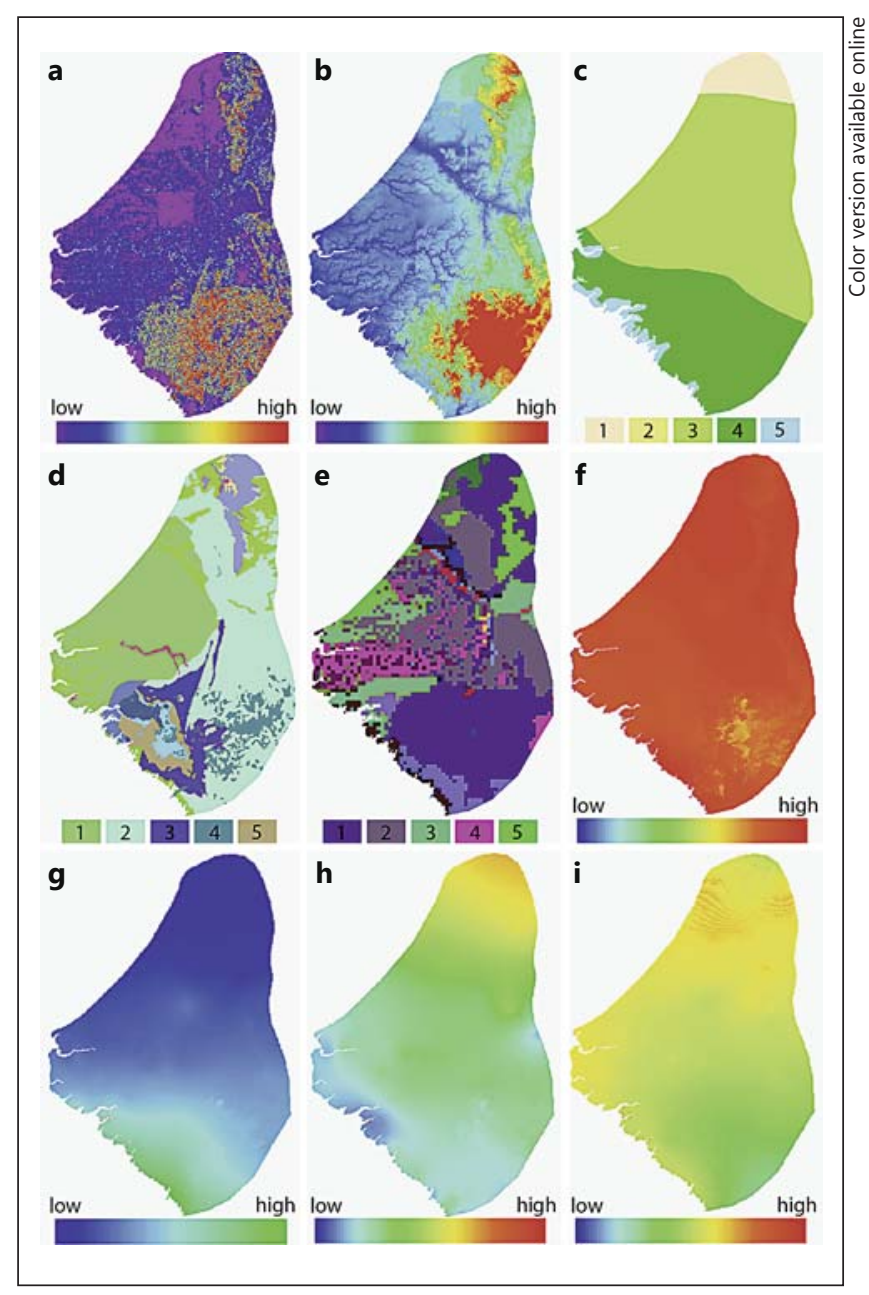

Fig. 2. Maps of the Guinea baboon range, including: terrain roughness (a); altitude (b); vegetation (c; boxes indicate $1=$ arid/semi-arid vegetation, $2=$ open vegetation, $3=$ semi-open vegetation, 4 = closed vegetation, $5=$ aquatic vegetation); surface geology (d) box $1=$ Tertiary, $2=$ Precambrian, 3 = Ordovician, 4 = Mesozoic igneous, 5 = Silurian); soil types (e; box $1=$ leptosol, $2=$ regosol, 3 = lixisol, $4=$ acrisol, 5 = arenosol); mean annual temperature (f); mean annual rainfall (g); temperature seasonality $(\mathbf{h})$, and rainfall seasonality (i).

able on baboon distributions do not allow us to say with certainty whether any of these sub-zero areas are permanently or even periodically occupied (they may represent areas within the range that are avoided), but the result is nonetheless interesting; mapping these areas at a finer resolution, and establishing their role as baboon habitats, would be an interesting continuation of this study. Olive baboons occupy areas of every vegetation type and lots of different soils and surface geologies. Their range is the second most variable for annual mean rainfall and terrain roughness. Average DOI: $10.1159 / 000362545$ 


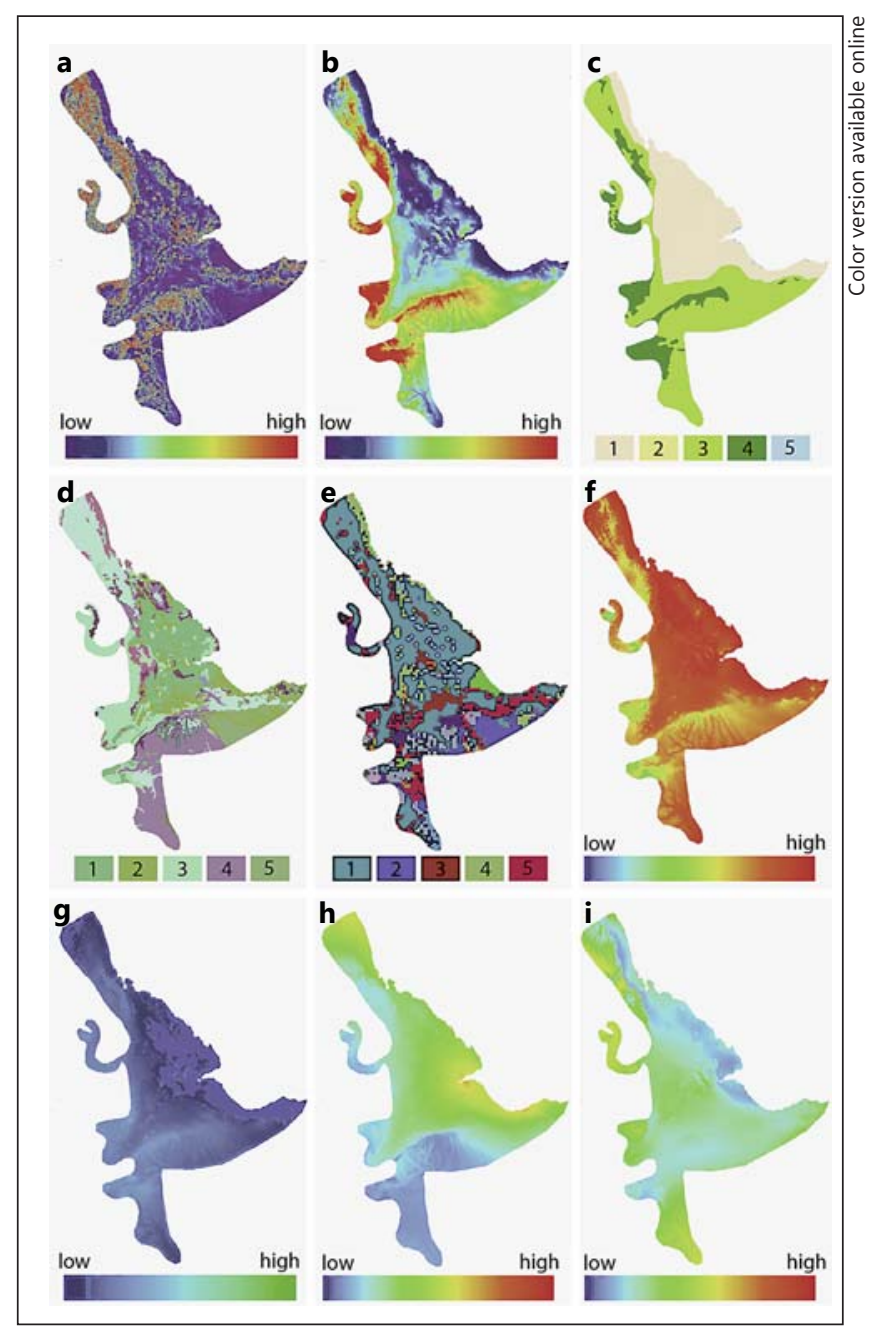

Fig. 3. Maps of the hamadryas baboon range, including: terrain roughness (a); altitude (b); vegetation (c; boxes indicate 1 = arid/semi-arid vegetation, 2 = open vegetation, 3 = semi-open vegetation, $4=$ closed vegetation, 5 = aquatic vegetation); surface geology (d; box $1=$ Quaternary igneous, 2 = Holocene, 3 = Tertiary igneous, 4 = Jurassic, 5 = Tertiary); soil types (e; box 1 = leptosol, 2 = calcisol, 3 = fluvisol, 4 = solonchak, 5 = cambisol); mean annual temperature (f); mean annual rainfall $(\mathbf{g})$; temperature seasonality $(\mathbf{h})$, and rainfall seasonality (i).

conditions in the olive baboon's range, however, are not very distinctive, except that it is the range with the joint lowest mean score for terrain roughness (0.017 units).

The yellow baboon range (fig. 5) lies to the south of the olive, Guinea and hamadryas ranges. It is therefore not surprising that it is generally cooler (mean annual temperature: $23.7^{\circ} \mathrm{C}$ ), though not as cold as the chacma range. It is distinctive, on average, only in having the lowest overall temperature seasonality (1,481.2 units). 


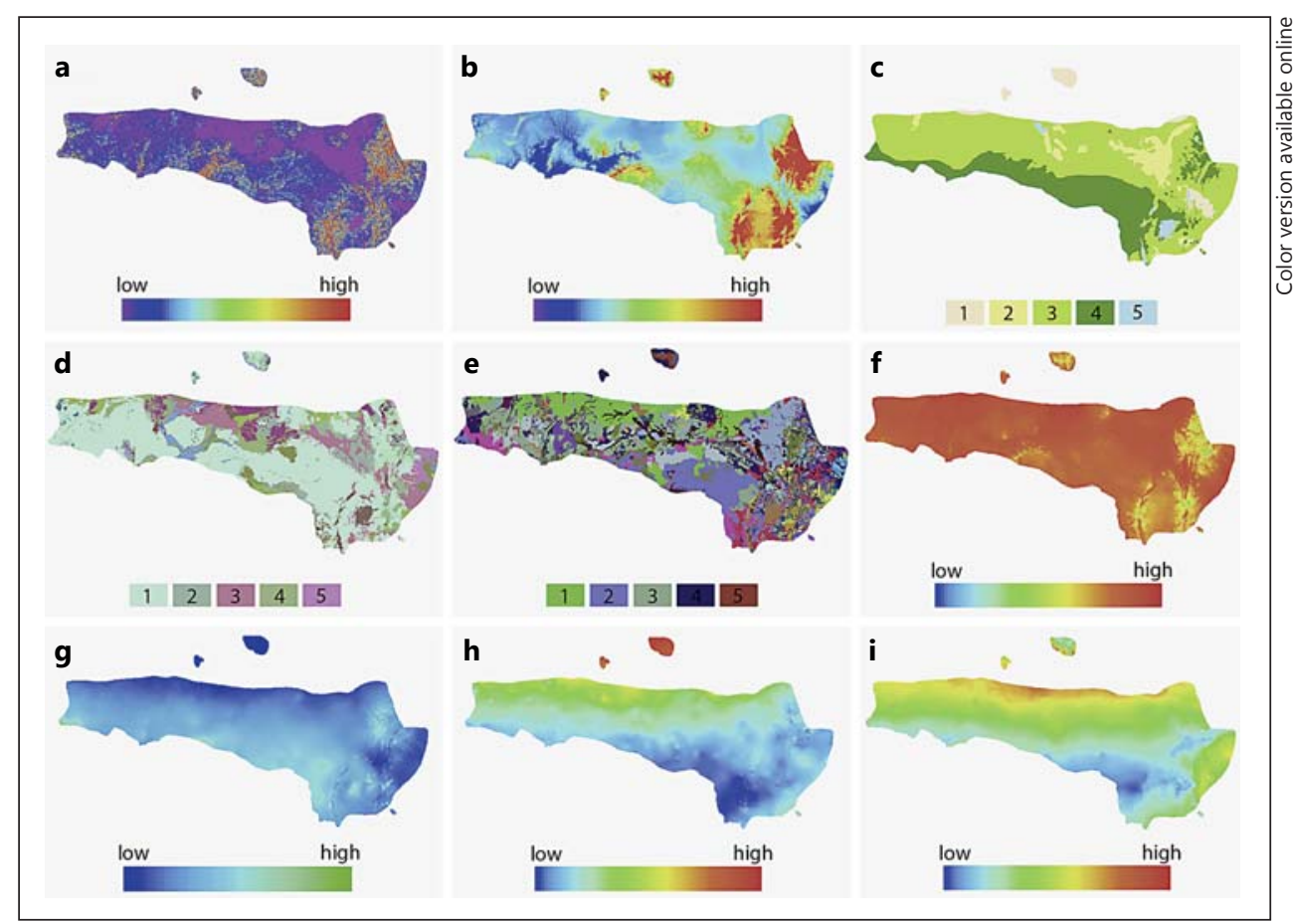

Fig. 4. Maps of the olive baboon range, including: terrain roughness (a); altitude (b); vegetation (c; boxes indicate 1 = arid/semi-arid vegetation, $2=$ open vegetation, $3=$ semi-open vegetation, 4 = closed vegetation, 5 = aquatic vegetation); surface geology (d; box $1=$ Precambrian, $2=\mathrm{Ce}-$ nozoic, $3=$ Quaternary, $4=$ Tertiary, 5 = Jurassic); soil types (e; box $1=$ arenosol, $2=$ ferralsol, 3 = lixisol, 4 = leptosol, 5 = bare rock); mean annual temperature (f); mean annual rainfall $(\mathbf{g})$; temperature seasonality $(\mathbf{h})$, and rainfall seasonality $(\mathbf{i})$.

Like the olive baboon range, in fact, that of the yellow baboon is quite internally variable - it spans a wide range of conditions for all variables but temperature seasonality, for which its range, 276-3,018 units, is just half that of the olive species. The yellow baboon occupies an area spanning the second largest range of altitude and rainfall seasonality scores (0-5,746 $\mathrm{m}$ and $27-164$ units, respectively) and is (as mentioned above) joint most variable in temperature. Its range is complex geologically and in terms of soils, and dominated by semi-open vegetation.

The kinda range (fig. 6) is roughly the same size as that of the yellow baboon, but less environmentally variable. In fact, the kinda range spans the second smallest range of values for all continuous variables: for altitude $(0-2,478 \mathrm{~m})$, terrain roughness (0-0.544 units), annual mean temperature $\left(16.2-28.3^{\circ} \mathrm{C}\right)$ and rainfall seasonality (40-133 units), it is only more variable than the Guinea baboon range, while for annual mean rainfall $(76-1,814 \mathrm{~mm} /$ year) and temperature seasonality (228-3,423 units), it is placed second after the hamadryas and yellow baboon ranges, respectively. In terms of mean values, the kinda range is distinctive only in being the wettest (mean annual rainfall: $1,228.3 \mathrm{~mm} /$ year), and is generally similar to the neighbouring 


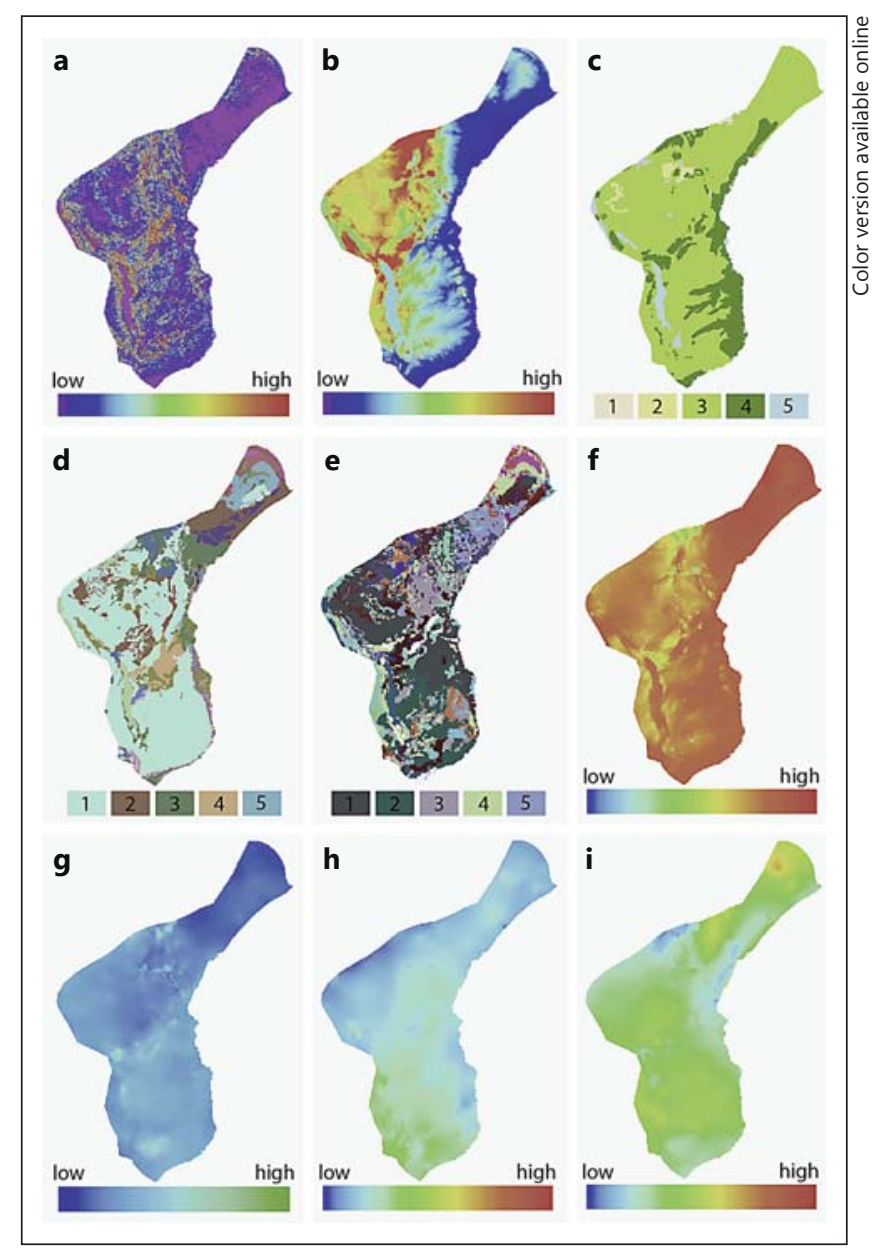

Fig. 5. Maps of the yellow baboon range, including: terrain roughness (a); altitude (b); vegetation (c; boxes indicate 1 = arid/semi-arid vegetation, 2 = open vegetation, $3=$ semi-open vegetation, 4 = closed vegetation, 5 = aquatic vegetation); surface geology (d; box 1 = Precambrian, $2=$ Quaternary, 3 = Holocene, $4=$ Jurassic-Carboniferous, $5=$ Jurassic); soil types (e; box $1=$ cambisol, 2 = lixisol, 3 = luvisol, 4 = leptosol, 5 = solonetz); mean annual temperature (f); mean annual rainfall $(\mathbf{g})$; temperature seasonality $(\mathbf{h})$, and rainfall seasonality $(\mathbf{i})$.

yellow baboon range in temperature and temperature seasonality. There are some clear spatial patterns in the geology and soils of the kinda range - most noticeably, a north-south ridge of Cenozoic rock overlain by arenosols - but overall these characters are variable. Its vegetation is dominated by semi-open and closed contexts.

The chacma baboon range (fig. 7), as the most southerly, is distinctive in being on average the coldest (mean temperature: $19.5^{\circ} \mathrm{C}$ ) and having the most seasonal temperatures (mean score: 3,728.4 units, compared to scores under 2,375 for all other species). It also has the second highest mean altitude $(984.4 \mathrm{~m})$ and roughness score 


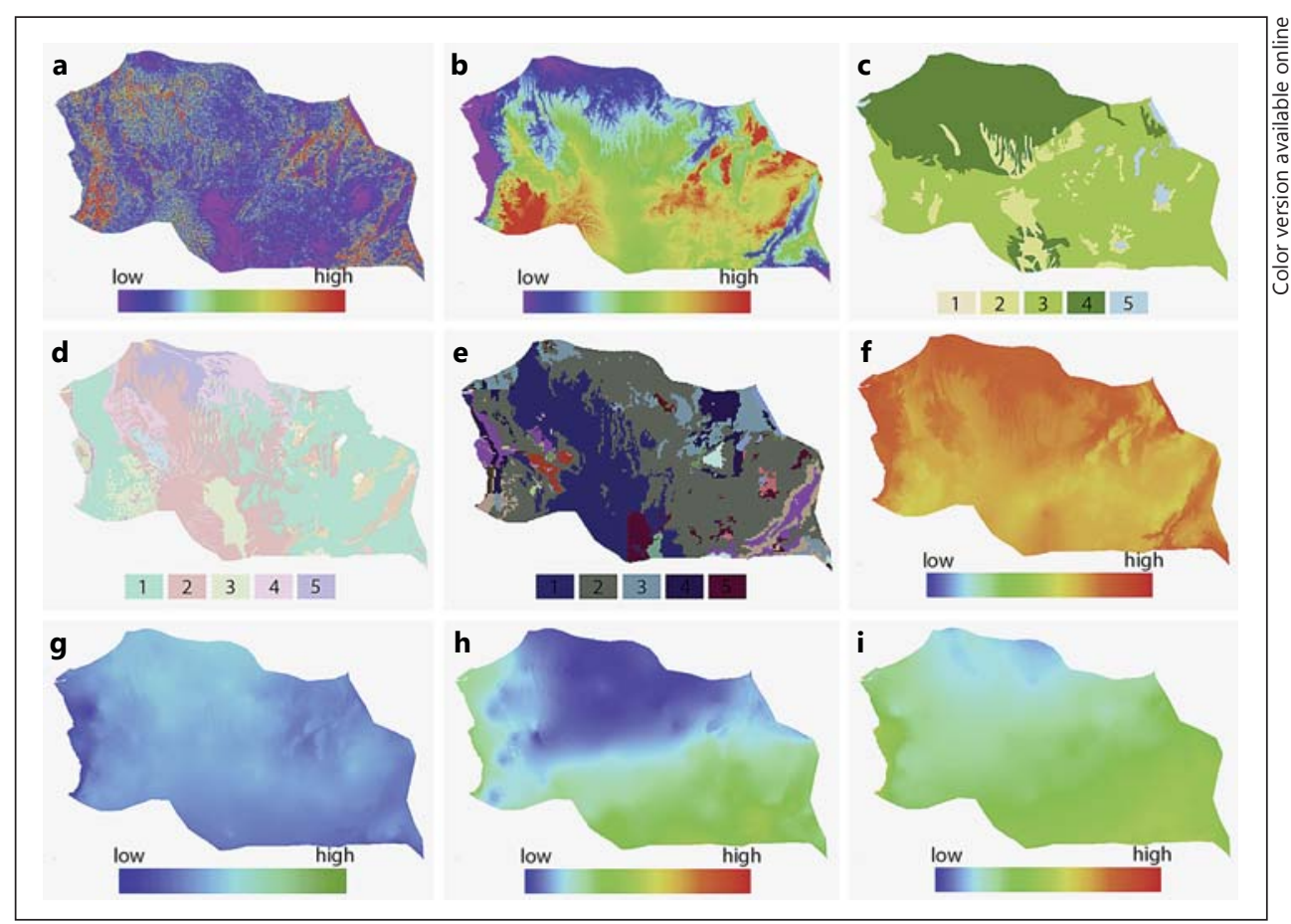

Fig. 6. Maps of the kinda baboon range, including: terrain roughness (a); altitude (b); vegetation (c; boxes indicate $1=$ arid/semi-arid vegetation, $2=$ open vegetation, $3=$ semi-open vegetation, 4 = closed vegetation, 5 = aquatic vegetation); surface geology (d; box $1=$ Precambrian, $2=\mathrm{Ce}$ nozoic, $3=$ Quaternary, $4=$ Lower Cretaceous, $5=$ Cretaceous); soil types (e; box $1=$ arenosol, 2 = ferralsol, 3 = acrisol, 4 = cambisol, 5 = gleysol); mean annual temperature (f); mean annual rainfall $(\mathbf{g})$; temperature seasonality $(\mathbf{h})$, and rainfall seasonality $(\mathbf{i})$.

(0.026 units), and low, relatively non-seasonal levels of rainfall (mean annual rainfall: $513.4 \mathrm{~mm} /$ year, mean rainfall seasonality: 84.7 units). This range also has the widest range of scores in terrain roughness ( $0-0.895$ units) and the second widest range for temperature seasonality $(5,489$ units, compared to 6,449 for the olive baboon, the only one with a wider range). Otherwise, its ranges for the continuous variables are intermediate, and it also shows considerable spatial variability in the distribution of soils, geological units and vegetation, which overall is dominated by semi-open contexts.

Within-Range Environmental Variability: How Much and How Systematic?

These summaries suggest that there may be a link between range size and environmental variability. Pearson's correlation coefficients for the relationships between range areas and the range of values each spans for the 6 continuous environmental variables, however, suggest this is not that simple. Only for rainfall seasonality was the correlation coefficient $(0.89)$ suggestive of a strong link with range geographic areas, while coefficients for area versus temperature seasonality (0.63), temperature 


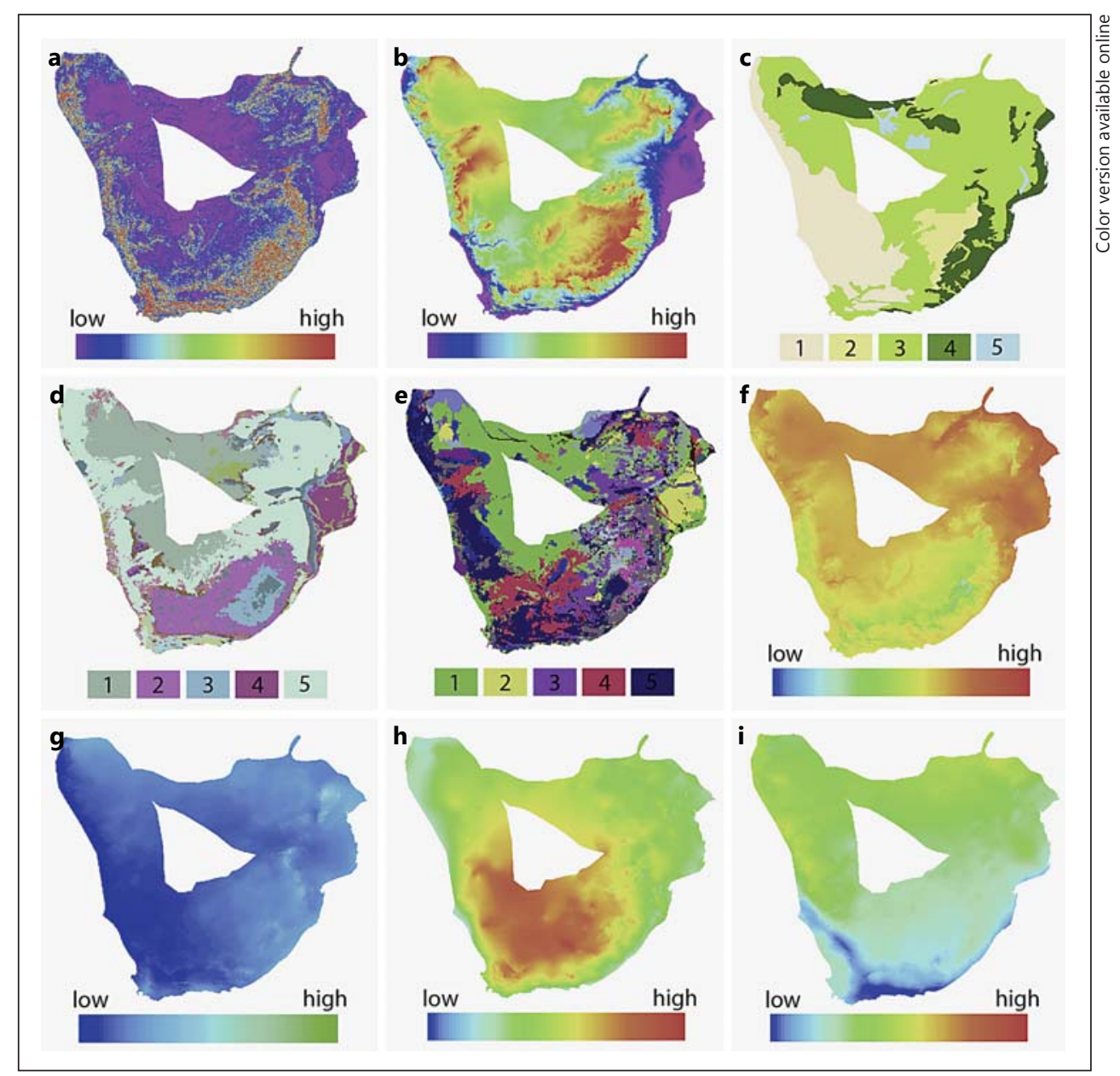

Fig. 7. Maps of the chacma baboon range, including: terrain roughness (a); altitude (b); vegetation (c; boxes indicate 1 = arid/semi-arid vegetation, 2 = open vegetation, 3 = semi-open vegetation, 4 = closed vegetation, 5 = aquatic vegetation); surface geology $(\mathbf{d}$; box $1=$ Cenozoic, $2=$ Permian, 3 = Triassic, $4=$ Pleistocene, $5=$ Precambrian); soil types $(\mathbf{e}$; box $1=$ arenosol, $2=$ solonetz, 3 = luvisol, 4 = cambisol, 5 = leptosol); mean annual temperature (f); mean annual rainfall (g); temperature seasonality $(\mathbf{h})$, and rainfall seasonality (i).

(0.51) and altitude (0.55) were moderate and those for roughness and rainfall were low ( 0.25 and 0.23 , respectively). Of these, only the strongest correlation - between area and rainfall seasonality - was statistically significant at the 0.05 level, with a $\mathrm{p}$ value of 0.019 ; the other $\mathrm{p}$ values ranged from 0.177 to 0.666 . When scores for each of the continuous variables were correlated with species' latitudinal ranges, however, there were 3 statistically significant relationships, between latitudinal range and altitude (correlation coefficient $=0.83, \mathrm{p}=0.039$ ), annual mean temperature (coefficient $=0.847, \mathrm{p}=0.033)$ and, once again, rainfall seasonality (coefficient $=0.937, \mathrm{p}=$ 
0.006). These results suggest that range size has some effect on the range of variability in the environments a species uses, but this does not explain all the observed variability.

Some of the figures above suggest that there may be definable subsections of individual species' ranges, that is that environments may be systematically patterned at the medium-small scale. Figure 2, for example, suggests that the Guinea baboon range may show systematic patterning. Vegetation and several climatic variables show latitudinal banding, and the landscape shows a broad split between the flatter, smoother north (covered by just a few geological units but variable soils) and a geological 'anomaly' of different rock and soil types, higher altitudes and higher roughnesses in the south-east. This raises a more general question: how do different environmental variables relate to one another within each species' range? To explore this, MCAs (see Method section for detail) were conducted for all 6 ranges.

An MCA, like a principal components analysis of continuous data, is a multivariate technique which summarises the variability in a set of variables (in this case, individual environmental components) and extracts simple sets of axes that describe it. Each MCA produces a set of axes that explain as much of the total variability as possible, and on these axes one can plot either the individual data points - in this case, localities - or the variables used. On a plot of variables (environmental components), the distance between 2 points indicates how close they are in the multidimensional space described. A cluster of points thus indicates a group of variables that typically co-occur, while a regular distribution of points suggests a more complex landscape with variables occurring in many different combinations rather than in systematic associations. As this latter condition suggests the sampled environments explore more of the multidimensional possibility space (the space of all possible environmental combinations) than is the case where there is clustering, a range with few clusters can be considered to have more within-range variability in the configuration of environments, and one with more clustering less variability and more systematic patterning. Here, I use a very simple definition of a 'cluster' as a group of 2 or more variables located close together with some noticeable distance (several times the distance separating members of the cluster) between themselves and their nearest non-cluster neighbours.

MCA of the Guinea baboon range produced 2 axes explaining 7.8 and $5.4 \%$ of total environmental variation, respectively. These low scores suggest that even here there is a lot of variability in the way environmental components associate, and any systematic pattern is not dominant. Figure 8 a shows the distribution of components on these axes, with clusters indicating co-occurring groups. On the far left, for example, a pair of dots representing low-medium altitudes (1,029-2,212 m) and medium roughnesses (0.298-0.596 units) plots close together, suggesting they co-occur. To the right, at about -1 on axis 1 , a loose cluster links lixisols, vertisols, regosols and solonetz soils, low-medium rainfall seasonalities (71-125 units) and moderate rainfall levels (956-2,862 mm/year). At $\sim 0$ on this axis, there are 2 more clusters. The uppermost comprises several geological units together with closed and aquatic vegetation zones (perhaps representing the southerly latitudinal band with its geological anomaly; see fig. 2), the lower links low roughnesses (0-0.298 units), low altitudes (-154 to1,029 m), Quaternary, Precambrian and Holocene geologies, semi-open vegetation and high temperatures $\left(24.6-32^{\circ} \mathrm{C}\right)$. This may represent some landscapes of the larger, more northerly part of the range (fig. 2). Finally, to the far right, a loose 

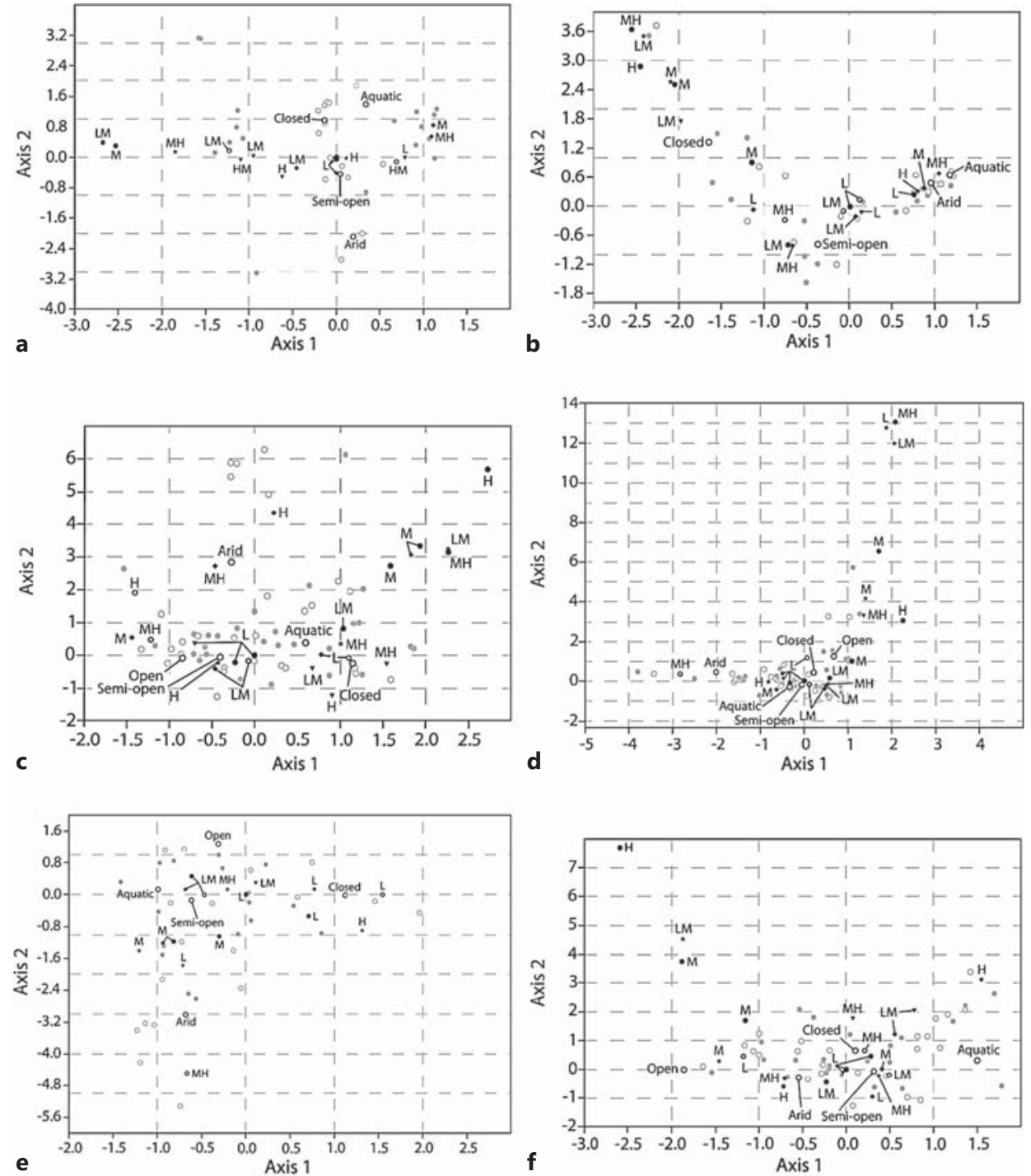

Fig. 8. Plots showing the distribution of different environmental components on axes 1 and 2 for each of the $6 \mathrm{MCAs}$, including the ranges of the Guinea (a), hamadryas $(\mathbf{b})$, olive (c), yellow (d), kinda (e) and ursinus baboons (f). Different symbols indicate different groups of components: black filled circle = roughness; dark grey filled circle = altitude; pale grey filled circle = soil unit; pale grey open circle = geological unit; black open circle = vegetation type; star = annual mean temperature category; triangle $=$ annual mean rainfall category; diamond $=$ temperature seasonality category; inverted star = rainfall seasonality category. Which specific component is represented by each point is indicated by the lettering associated with the symbol: $\mathrm{L}=$ low; $\mathrm{LM}=$ lowmedium; $\mathrm{M}=$ medium; $\mathrm{MH}$ = medium-high; $\mathrm{H}=$ high values (table 3 gives details of how these labels are defined for each variable). 
cluster links moderate temperature seasonalities (2,651-5,231 units) to low rainfalls (3-956 mm/year) and the presence of gleysols, acrisols, cambisols and several other soil or geological units. These environments probably also occur on the northern flats, though their placement in a separate cluster makes this less certain. The top of the spread on axis 2 links salt flats and nitirols, while the base shows a cluster that links arid/semi-arid habitats and Ordovician-Cambrian geologies (which co-occur in some parts of the extreme north of the Guinea range). There thus is some systematic pattern in the environments of the Guinea baboon range, some of which is visible on the larger-scale maps in figure 2 and some of which seems to occur at smaller scales.

The first 2 axes for the hamadryas range MCA explained 8.9 and $6.3 \%$ of total variation (fig. 8b). These values are slightly higher than in the Guinea baboon MCA, but probably not sufficiently so to imply a really significant difference in the strength of patterning. There are some clusters on figure $8 \mathrm{~b}$ too. In the top left, a loose cluster links Ordovician rocks, chernozems, medium-high altitudes (3,395-4,578 m) and low-medium temperatures $\left(2.4-9.8^{\circ} \mathrm{C}\right)$. Below and to the right of this, medium temperatures $\left(9.8-17.2^{\circ} \mathrm{C}\right)$ and medium altitudes $(2,212-3,395 \mathrm{~m})$ are closely linked, while in the centre of the plot there are no clear clusters, but instead a series of environmental components roughly evenly distributed across the area, presumably all weakly associated and occurring in different combinations. There is, however, a closer association between Triassic-Permian geologies and medium roughnesses (0.298-0.596 units) within this mega-cluster. At about -1 on axis 2 and -0.6 on axis 1, Jurassic rocks, medium-high temperatures $\left(17.2-24.6^{\circ} \mathrm{C}\right)$ and low-medium altitudes (1,029-2,212 $\mathrm{m}$ ) form a loose cluster which might also include the andosols and phaeozems and semi-open contexts, though again it grades into other, more widely spaced, groups. To the far right, there are 2 large, relatively tight clusters. The first links low or low-medium rainfall seasonalities (20-125 units), leptosols, regosols, low roughnesses ( $<0.298$ units), low rainfalls $(3-956 \mathrm{~mm} /$ year), lowmedium temperature seasonalities (1,361-2,651 units) and Lower Cretaceous, Precambrian and Holocene rocks. The second links arid/semi-arid vegetation, Pleistocene, Palaeozoic igneous, Triassic and Quaternary rocks, histosols, gypsisols and solonchaks, low altitudes $(<1,029 \mathrm{~m})$, medium temperature seasonalities $\left(2,651-3,941\right.$ units) and high temperatures $\left(>24.6^{\circ} \mathrm{C}\right)$. This cluster seems (fig. 3) likely to represent the coastal plain to the north-east of the hamadryas range, but the correspondence is imperfect and it is hard to identify areas which might be represented by other clusters. This implies that while there again is some systematic environmental patterning in the hamadryas range, it is more complex and less visible on the large-scale maps than in the Guinea baboon range and may occur at smaller (subregional) scales.

Axes 1 and 2 from the olive baboon MCA explained 5.5 and 3.3\% of total variation, suggesting less systematic patterning here than in the Guinea or hamadryas ranges. The resulting plot (fig. 8c) confirms this; instead of forming clusters, the environmental components here are more evenly distributed, especially on axis 1 . There are few, if any, clearly discernable clusters, with the possible exception of 1 of 3 points at the top of the graph (approx. -0.25 on axis 1 ) comprising Devonian, Upper/Middle Devonian and Carboniferous rocks and a few pairs off towards the right-hand side of the plot which may represent loose clusters but may equally be the tail of the more regular, random distribution in the centre. This implies great heterogeneity in the composition of olive baboon environments, and a general lack of visibility at this scale 
for what systematic patterning is present, supported by the fact that it is hard to identify subranges characterised by these clusters in figure 4 .

The first 2 axes for the yellow baboon MCA explained 4.3 and 3.9\% of total variation. The resulting plot (fig. 8d) also shows only a few clearly defined clusters. These include one at the top right, linking medium-high altitudes $(3,395-4,578 \mathrm{~m})$ with low and low-medium temperatures $\left(-5\right.$ to $\left.9.8^{\circ} \mathrm{C}\right)$ and a second below and to the left of the first ( 3-4 on axis 2 and $\sim 1.3$ on axis 1$)$ linking medium temperatures $\left(9.8-17.2^{\circ} \mathrm{C}\right.$ ), andosols, medium-high rainfalls (1,909-2,862 mm/year), Quaternary igneous rocks and, more loosely, Tertiary igneous rocks and high roughnesses (0.596-0.895 units). Neither is easily visible in figure 5 , however, perhaps because the rock and soil units involved are not any of the major ones identified in overall summaries of the range. Directly below the latter group is a very close cluster of 3 soils (alisols, chernozems and greyzems) with medium roughness scores (0.298-0.596 units). Again, these are not major components of the wider yellow range, suggesting local systematic patterning not visible at the larger scale. A final clear cluster, at approximately -1.6 on axis 1, links Cenozoic, Cretaceous, Jurassic and Cambrian rocks, gleysols, solonchaks and solonetz soils and, more loosely, arid/semi-arid vegetation. Both Jurassic rocks and solonetz soils appear in figure 5 towards the narrow point in the north-east of the yellow baboon range, as do small areas of arid/semi-arid vegetation, so this cluster may represent this area. This suggests that while systematic patterning in the yellow baboon range, like that of the olive baboon, is less consistent and less visible on largerscale maps than was the case for the Guinea baboon species, it may exist in some areas at smaller scales.

The kinda baboon MCA produced axes explaining 7.4 and 5.1\% of variation, respectively (fig. 8e). These values are comparable to the Guinea baboon ones, but the plot seems to show very little clustering of environmental components. In fact, while there are a few possible clusters in the association of pairs or triplets of variables, these are typically embedded in looser groups of variables and do not fit the definition of a cluster given above well enough to be singled out. The major features in figure 6, the ridge and surrounding landscapes, are thus much less clear in the more comprehensive analysis of kinda baboon environments in figure 8e: arenosols and Cenozoic rocks (the ridge units) plot out quite close to one another, but ferralsols and Precambrian rocks (from the surroundings) are only weakly associated.

The final MCA, of the chacma baboon range, produced axes explaining 4.8 and $3.6 \%$ of total variation, and showed relatively little evidence of clustering (fig. 8f). This is especially interesting when we note that figure 7 seems to show some systematic difference between the environments of the north and south chacma baboon ranges, particularly in climate. In fact, in figure $8 \mathrm{f}$, there are just 3 potentially distinct clusters of environmental components and none of these is very convincing. Either way, their association is unlikely to be informative. The only one which possibly meets the definition of a cluster used here is the pair of points at $\sim 4$ on axis 2 , representing low-medium temperatures $\left(2.4-9.8^{\circ} \mathrm{C}\right)$ and medium altitudes $(2,212-3,395 \mathrm{~m})$. These could, however, merely be two outliers that happen to fall on the same side of the main plot, as they do not cluster very tightly. The chacma range thus also seems to have little systematic patterning in the distribution of different environmental components and, instead, to encompass environments with highly variable configurations. One final point regarding the chacma range relates to the presence of a large gap in the species' distribution, taking in parts of Botswa- 
na and the edges of neighbouring countries. The reason for this gap remains unclear, but extending the types of analysis in this paper to encompass this region might be a useful extension of the current project (as, indeed, might be the case for an even broader analysis comparing the occupied and unoccupied parts of subSaharan Africa).

\section{Discussion}

The MCAs performed above suggested that while some systematic patterning was present in baboon environments, it was small-scale and did not typically correspond to the patterns visible on larger-scale maps. The taxon for which it was most apparent on these maps, moreover, was the Guinea baboon, which has the geographically smallest range and for which subregional patterns were therefore more likely to be visible. This implies that small-scale variability may be important to baboon evolutionary ecology, perhaps even more so than the seemingly less coherent regional patterns. To explore this idea further, 3 small-scale case studies are developed here. They focus on the olive baboons of Gashaka Gumti National Park, Nigeria/ Cameroon, the chacma baboons at De Hoop Nature Reserve in South Africa and the yellow baboons of Amboseli National Park, Kenya. The first two investigate the presence and potential importance of differences in the environments occupied by neighbouring troops, the third that of temporal environmental change over a few decades.

\section{Olive Baboons at Gashaka Gumti}

Gashaka Gumti National Park is home to 2 well-known troops of baboons, the Gamgam and Kwano troops. These live in similarly sized home ranges just $10 \mathrm{~km}$ from one another [Warren et al., 2011] but occupy distinctly different local environments. In particular, the Gamgam troop range has a higher proportion of grassland and open vegetation than the Kwano troop, which has more lowland and gallery forest [Ross et al., 2011]. Climate also differs, though both fall within the same regime of high temperatures and highly seasonal rainfall [Warren et al., 2011]. The Gamgam troop's range is slightly warmer and drier (with a mean annual temperature of $26.8^{\circ} \mathrm{C}$ and 1,897 mm/year rainfall), while the Kwano troop's is cooler and wetter (mean annual temperature $26.4^{\circ} \mathrm{C}$ and $1,973 \mathrm{~mm} /$ year of rainfall) [Ross et al., 2011]. Finally, the two ranges also differ in altitude, with the Gamgam troop's range at about $320 \mathrm{~m}$ and the Kwano's at $583 \mathrm{~m}$ [Warren et al., 2011].

This brief summary suggests that for the Gashaka baboons at least, small-scale environmental variability is noticeable. But does it impact their ecology? The two certainly differ. The Gamgam troop eats crops and wild foods [Warren, 2008], for example, while Kwano baboons live exclusively on the latter [Warren et al., 2011]. Despite their access to crops, however, the Gamgam troop is smaller, with an average of 19.3 individuals and a range of 14-23 compared to the Kwano troop's 28.4, range 26-35 [Ross et al., 2011]. A study of their ecologies by Ross et al. [2011] also noted that the Gamgam troop spends more time resting and socialising, travels further in an average day and reproduces at shorter interbirth intervals and with lower infant mortality than do their neighbours. These reproductive effects are likely linked to crop-raiding and anthropogenic influence, but the influences of humans 
on troop size, activity budgets and ranging are probably smaller [Warren et al., 2011]. It is quite likely that the environmental differences have an ecological impact here, though this has yet to be proven. It is also interesting to note that although at Gashaka we cannot roll back the clock to identify 'natural' (as opposed to anthropogenically influenced) ecological and biogeographic patterns, there may be more to the relationship than a simple release from external pressures as a result of cropraiding.

\section{Chacma Baboons at De Hoop}

The Vlei and Small troops of chacma baboons at De Hoop occupy very different overall contexts to those at Gashaka. They live much further south in a region dominated by fynbos vegetation, nearer sea level and on the coast. Once again, however, there are environmental differences between the two troops' ranges, despite the fact that they overlap in some areas [Hill, 1999]. In particular, the Small troop occupies landscapes with higher average slope values (i.e. more variable altitudes) and has significantly more access to cliff refuges than the Vlei troop [Hill, 1999]. The vegetation composition of the two ranges is also different: the Small troop uses a range which is dominated by burnt fynbos and fynbos, with smaller areas of vlei and acacia woodland and almost no grassland, while in the overlapping Vlei range the burnt fynbos/ fynbos categories are less dominant, and the proportions of vlei, acacia woodland and grassland are higher [Hill, 1999]. There are no discernible climatic differences between the two.

These environmental differences seem smaller than those seen at Gashaka, but there are still ecological differences between the two troops at De Hoop which may be related to them. The Small troop is smaller, at 17-21 individuals compared to the Vlei troop's $40-44$, and its members spend more of their time feeding (58\% compared to $36.3 \%$ ), perhaps because they spend more of the day, on average, close to sleeping sites and in lower quality habitats than do members of the Vlei troop [Hill, 1999]. Hill [1999] suggests that for the baboons at De Hoop, troop size may be particularly important, as it determines how a group can make use of the environment. The larger Vlei troop, he proposes, is pushed by the shorter and more seasonal day lengths that prevail in South Africa into spending more time in high-quality but risky habitats, while the Small troop's lower numbers mean it does not have to do the same. At De Hoop, then, small-scale variation in baboon environments is present just as it is at Gashaka, but the nature of the feedback between environment and ecology is different. In particular, at De Hoop it seems that environmental variability affects baboon ecology, while at Gashaka (where crop-raiding is more common) ecological strategies may be selected independently of local environments. There, the baboon-environment relationship may be steered by socio-ecology as much (or more than) by environmental conditions. Even just these two case studies, furthermore, make it very clear just how complex baboon-environment relationships can be at the small scale. These analyses thus strongly suggest that further research into the within-range distribution of baboons - and how this changes through time and space and in response to human activity - is needed.

Yellow Baboons at Amboseli

The final case study given here is from Amboseli, and focuses on the 'main group' of baboons in the park [Altmann and Altmann, 1970], for which there is an extensive 
$\geq 25$-year data set on environment and baboon ecology [Altmann et al., 2002]. The data from Amboseli cover a period of marked environmental change. Between 1976 and 2000, the mean daily maximum temperature increased by $0.275^{\circ} \mathrm{C} /$ year, a total change of nearly $7^{\circ} \mathrm{C}$ [Altmann et al., 2002]. There was no trend in rainfall, which was highly variable throughout but for a severe drought in 1960-1961 followed by several years of heavy rainfall [Altmann et al., 1985]. This triggered tree loss, as the water table rose and water, with entrained salts from the soils, invaded their roots [Altmann et al., 1985]. By 2001, the area had shifted from an acacia woodland-grassland mosaic into one dominated by grasslands, open water and salt pans [Altmann et al., 2002; Western, 2007].

These environmental changes have had a clear impact on the main group. The number of baboons in Amboseli shrank from 2,500 in 1963 to 123 in 1979, and stabilised at just 150 or so in the mid-1980s [Altmann et al., 1985]. Troop sizes in the park as a whole have correspondingly shrunk, and the ranges each troop uses have changed: those using only wild foods have increased their ranges to $\sim 40 \mathrm{~km}^{2}$, while a few have taken to scavenging garbage and reduced theirs to $\sim 4 \mathrm{~km}^{2}$ [Altmann and Altmann, 1970; Altmann and Muruthi, 1988]. A key change seems to be the lowering of infant and juvenile survival rates, perhaps because of increased fluctuations in food distributions [Altmann et al., 1977; Altmann et al., 1985; Samuels and Altmann, 1991]. In addition, Bronikowski and Altmann [1996] note that models that attempt to relate baboon behaviour and ecology to local environmental conditions can find quite different relationships for different troops in the same park. This was the case at Amboseli even where two troops shared the same overall ecological strategy (both wild feeding) and the environmental differences they experienced were fairly small [Bronikowski and Altmann, 1996]. They suggest, as I have done in this paper, that small-scale variability can be very important to understanding baboon ecology, and that broader models, like those discussed in the introduction to this paper [Dunbar, 1992; Bettridge et al., 2010], while useful at larger scales, cannot always explain the observed differences effectively. This case study shows, therefore, that changes in local environments over years or decades may have significant impacts upon baboon ecology. Both spatial and temporal variability within a baboon species' range may be important to their biogeography and ecology. There is clearly a need for a better understanding of micropopulation dynamics and the distributions of baboons within their ranges if we wish to develop a better understanding of the ecology, evolution and biogeography of Papio.

Bigger Issues: Within-Range Distributions and Small-Scale Complexity

These 3 case studies also offer an opportunity to consider one of the key challenges to the approach to baboon biogeography tested in this paper: our lack of knowledge of the precise distribution of baboons within each species' range. I mentioned above that the fact that only two species' ranges include areas with annual mean temperatures below zero does not necessarily imply that these areas are used; they might be systematically avoided by baboons. One means of addressing this problem lies in coupling large-scale work, like that described here, with this type of small-scale analysis, although the latter must often be qualitative as really small environmental fluctuations are rarely (if ever) known in sufficient detail to be analysed quantitatively.

In fact, the same goes for analyses making use of point data on baboon localities, which do after all exist in gazetteers and detailed studies. As the introduction to this 
paper mentioned, point sample spots rarely systematically sample the full range of a baboon species, and we do not yet know how reliable the inference is that because one (or more) baboons were trapped here at a given time, this point must be part of a troop's permanent range and regularly used. Only with a great deal more detailed data collection will we be able to answer these questions, though the MCAs presented above do suggest certain useful avenues for further work. In addition to exploring areas of low overall temperature, for example, it would be interesting to know more about the gap in the chacma baboon range (and whether conditions there correspond to those in any areas they systematically avoid in their day-to-day lives), and, indeed, small-scale explorations of the 'extremes' of each range (and particularly on baboons' use of places with conditions not mirrored in other ranges) would be very interesting. In addition, it was interesting that the chacma (or 'mountain') baboon range was not, overall, the highest in altitude: is this because the designation is inaccurate or is there something more complex going on? For instance, do the hamadryas baboons actually occupy the highest-altitude parts of their range, or are these areas encompassed but not used (which might suggest, if the chacma baboons do use their mountains, that there is a difference in the two species' tolerances)? Following up some of these questions would be very interesting, and would allow us to refine (and ultimately perhaps replace) the IUCN data used as a starting point for this analysis.

One of the most suggestive results of this paper has been that, with the partial exceptions of the two smallest ranges, all the areas occupied by baboons are highly environmentally diverse. None of the MCAs found axes with very high explanatory power, and there was little systematic patterning visible in most ranges. Instead, the ranges of the olive, yellow, kinda and chacma baboons seem to span relatively large proportions of the possibility space of all possible environmental configurations, and a great deal of the variation present seems to be random. Placing these results in context, by considering existing data on small-scale patterning in baboon ranges, only emphasises the complexity of the baboon-environment relationship that controls their biogeography.

\section{Conclusions}

The above analyses of the environments used by the 6 Papio species demonstrated first that there are some overall differences in the conditions each occupies. These differences include some in climate and vegetation, long known to be important to baboon ecology and, potentially, biogeography [Dunbar, 1996; Hill and Dunbar, 2002], and others in less widely studied variables like surface geology, soils and terrain types. They are, however, often small, and it is the geographically smaller ranges which are more environmentally distinctive. The significance of these results lies not in the precise nature of the small differences between ranges, but in the fact that they suggest there is little evidence of overall niche differentiation between baboon species. Subject to the constraints of uncertainty over within-range distributions (outlined above), this is an interesting finding and allows for the later sections of this paper to begin to point the way towards a more nuanced understanding of baboon biogeography.

Further exploration of the relationship between range size and the magnitude of within-range environmental variability demonstrated that, in fact, it was gener- 
ally only weak to moderate in strength. Only for rainfall seasonality was there a strong and significant correlation between range area and the range of values spanned, though there were strong, significant correlations with latitudinal range for 3 variables, namely rainfall seasonality, altitude and annual mean temperature. Detailed analyses of within-range environments and particularly of the question of systematic patterning - whether there are certain sets of environmental conditions that regularly co-occur, and whether these occurred at regional or smaller scales (which is potentially significant for their evolutionary ecology) - were needed. MCAs performed on the environments in each range found a significant level of within-range variability. The smallest range, that of the Guinea baboon, showed the most recognisable regional systematic patterning, though even here there was substantial non-systematic variability and a wide range of environmental configurations was represented. For the other 5 species, 'subranges' were less obvious and the visible clusters of co-occurring environmental components were typically much smaller in scale and not very clear on larger-scale maps. That small-scale variability exists and can impact baboon ecology was supported by 3 case studies from different parts of Africa, each of which found different baboon-environment relationships but all with evidence for the influence of local environmental heterogeneity on the inhabitants' ecology.

Overall, then, this paper has suggested that baboon environments are complex and variable at many spatiotemporal scales. The heterogeneous relationships between baboons and their contexts may not be immediately apparent except with an explicitly spatial or biogeographic (or at least more widely comparative) perspective, but deserve further exploration. This implies that analyses which aim to link visible differences between baboon species to 'average' differences in their environments, or to characterise their distributions in terms of simple preferences or constraints, are likely to oversimplify matters to a point where meaningful information is scarce. The variability in environments within a species' range dwarfs the differences between them - the same pattern Kamilar [2006] found for baboon socio-ecology. There are several possible corollaries. It may be that chance, agency and choice have played a more important role in baboon biogeography than we have previously considered as, perhaps, was the case for our ancestors. Alternatively, it might be that the controls on baboon distributions are more intricate - to do with aspects of the combinations of environments and/or taxa present that do not appear on simple maps. Either way, this work confirms the huge ecological flexibility of the Papio baboons and suggests that further work on the complexities of their evolutionary ecology and biogeography at various scales would be informative.

\section{Acknowledgements}

I would like to acknowledge funding from the European Research Council (ERC Project 269586 DISPERSE), the Holbeck Charitable Trust, the Leathersellers' Company Charitable Fund, the Department of Archaeology (University of York) research fund and a Charles A. Lockwood Memorial Grant, administered by the Primate Society of Great Britain. I am also grateful to Sarah Elton and 3 anonymous reviewers for their helpful comments on earlier versions of this paper. 


\section{References}

Altmann J, Muruthi P (1988). Differences in daily life between semiprovisioned and wild-feeding baboons. American Journal of Primatology 15: 213-221.

Altmann J, Alberts SC, Altmann SA, Roy SB (2002). Dramatic change in local climate patterns in the Amboseli basin, Kenya. African Journal of Ecology 40: 248-251.

- Altmann J, Altmann S, Hausfater G (1981). Physical maturation and age estimates of yellow baboons, Papio cynocephalus, in Amboseli National Park, Kenya. American Journal of Primatology 1:389-399.

Altmann J, Altmann S, Hausfater G, McCuskey S (1977). Life history of yellow baboons: physical development, reproductive parameters, and infant mortality. Primates 18: 315-330.

-Altmann J, Hausfater G, Altmann SA (1985). Demography of Amboseli baboons, 1963-1983. American Journal of Primatology 8: 113-125.

Altmann SA, Altmann J (1970). Baboon Ecology: African Field Research. Chicago, University of Chicago Press.

Arnold ML (2009). Reticulate Evolution and Humans: Origins and Ecology. Oxford, Oxford University Press.

Barrett L, Henzi SP (2008). Baboons. Current Biology 18: R404-R406.

Bettridge C, Lehmann J, Dunbar RIM (2010). Trade-offs between time, predation risk and life history and their implications for biogeography: a systems modelling approach with a primate case study. Ecological Modelling 221: 777-790.

Bettridge CM, Dunbar RIM (2012). Modeling the biogeography of fossil baboons. International Journal of Primatology 33: 1278-1308.

Bronikowski AM, Altmann J (1996). Foraging in a variable environment: weather patterns and the behavioural ecology of baboons. Behavioural Ecology and Sociobiology 39: 11-25.

Burrell AS, Jolly CJ, Tosi AJ, Disotell TR (2009). Mitochondrial evidence for the hybrid origin of the kipunji, Rungwecebus kipunji (Primates: Papionini). Molecular Phylogenetics and Evolution 51: 340348.

Dunbar RIM (1988). Primate Social Systems. London, Chapman \& Hall.

Dunbar RIM (1992). Time: a hidden constraint on the behavioural ecology of baboons. Behavioural Ecology and Sociobiology 31: 35-49.

Dunbar RIM (1996). Determinants of group size in primates: a general model. In Evolution of Social Behaviour Patterns in Primates and Man (Runciman WG, Maynard Smith J, Dunbar RIM, eds.), pp 33-57. Oxford, Oxford University Press.

Eeley HAC, Foley RA (1999). Species richness, species range size and ecological specialisation among African primates: geographical patterns and conservation implications. Biodiversity and Conservation 8: $1033-1056$

FAO/IIASA/ISS-CAS/JRC (2009). Harmonised World Soil Database (version 1.1). Rome and Laxenburg, FAO and IIASA.

Farr TG, Rosen PA, Caro E, Crippen R, Duren R, Hensley S, Kobrick M, Paller M, Rodriguez E, Roth L, Seal D, Shaffer S, Shimada J, Umland J, Werner M, Oskin M, Burbank D, Alsdorf D (2007). The Shuttle Radar Topography Mission. Reviews of Geophysics 45: 33.

Groves C (2001). Primate Taxonomy. Washington, Smithsonian Institution Press.

Hammer $\varnothing$, Harper DAT, Ryan PD (2001). Paleontological statistics software package for education and data analysis. Palaeontologica Electronica 4: 1-9.

- Henzi P, Barrett L (2003). Evolutionary ecology, sexual conflict, and behavioral differentiation among baboon populations. Evolutionary Anthropology: Issues, News, and Reviews 12: 217-230.

Higham JP, Warren Y, Adanu J, Umaru BN, MacLarnon AM, Sommer V, Ross C (2009). Living on the edge: life-history of olive baboons at Gashaka-Gumti National Park, Nigeria. American Journal of Primatology 71: 293-304.

Hijmans RJ, Cameron SE, Parra JL, Jones PG, Jarvis A (2005). Very high resolution interpolated climate surfaces for global land areas. International Journal of Climatology 25: 1965-1978.

Hill RA (1999). Ecological and Demographic Determinants of Time Budgets in Baboons: Implications for Cross-Populational Models of Baboon Socioecology. PhD thesis, University of Liverpool.

Hill RA (2006). Thermal constraints on activity schedule and habitat choice in baboons. American Journal of Physical Anthropology 129: 242-249.

Hill RA, Dunbar RIM (2002). Climatic determinants of diet and foraging behaviour in baboons. Evolutionary Ecology 16: 579-593.

Hill RA, Barrett L, Gaynor D, Weingrill T, Dixon P, Payne H, Henzi SP (2003). Day length, latitude and behavioural (in)flexibility in baboons (Papio cynocephalus ursinus). Behavioural Ecology and Sociobiology 53: 278-286.

Hill RA, Lycett JE, Dunbar RIM (2000). Ecological and social determinants of birth intervals in baboons. Behavioral Ecology 11: 560-564. 
IUCN (2012). IUCN Red List of Threatened Species. Version 2012.1. http://www.iucnredlist.org (accessed February 1, 2012).

IUCN (2013). Mammals on the IUCN Red List: description of data. http://www.iucnredlist.org/initiatives/mammals/description (accessed December 28, 2013).

-Jolly CJ (2001). A proper study for mankind: analogies from the Papionin monkeys and their implications for human evolution. American Journal of Physical Anthropology 116: 177-204.

- Jolly CJ, Burrell AS, Phillips-Conroy JE, Bergey C, Rogers J (2011). Kinda baboons (Papio kindae) and grayfoot chacma baboons ( $P$. ursinus griseipes) hybridize in the Kafue river valley, Zambia. American Journal of Primatology 73: 291-303.

-Jolly CJ, Woolley-Barker T, Beyene S, Disotell TR, Phillips-Conroy JE (1997). Intergeneric hybrid baboons. International Journal of Primatology 18: 597-627.

- Kamilar JM (2006). Geographic variation in savanna baboon (Papio) ecology and its taxonomic and evolutionary implications. In Primate Biogeography (Lehman SM, Fleagle JG, eds.), pp 169-200. New York, Springer.

Kindt R, Osino D, Orwa C, Nzisa A, van Breugel P, Graudal L, Lilleso J-PB, Kehlensbeck K, Dietz J, Nyabenge M, Jamnadass R, Neufeld H (2011). Useful Tree Species for Africa: Interactive Vegetation Maps and Species Composition Tables Based on the Vegetation Map of Africa. Nairobi, World Agroforestry Centre.

Kingdon J (1997). The Kingdon Field Guide to African Mammals. San Diego, Academic Press Natural World.

Kunz BK, Linsenmair KE (2008). The disregarded west: diet and behavioural ecology of olive baboons in the Ivory Coast. Folia Primatologica 79: 31-51.

- Newman TK, Jolly CJ, Rogers J (2004). Mitochondrial phylogeny and systematics of baboons (Papio). American Journal of Physical Anthropology 124: 17-27.

Ross C, Warren Y, Maclarnon AM, Higham JP (2011). How different are Gashaka's baboons? Forest and open country populations compared. In Primates of Gashaka: Socioecology and Conservation in Nigeria's Biodiversity Hotspot (Sommer V, Ross, C, eds.), pp 333-360. New York, Springer.

- Samuels A, Altmann J (1991). Baboons of the Amboseli Basin: demographic stability and change. International Journal of Primatology 12: 1-19.

Sechrest WW (2003). Global Diversity, Endemism and Conservation of Mammals. $\mathrm{PhD}$ thesis, University of Virginia.

- Sharman M, Dunbar RIM (1982). Observer bias in selection of study group in baboon field studies. Primates 23: 567-573.

- Stone OML, Laffan SW, Curnoe D, Herries AIR (2013). The spatial distribution of chacma baboon (Papio ursinus) habitat based on an environmental envelope model. International Journal of Primatology 34: 407-422.

Sturdy D, Webley D, Bailey G (1997). The Palaeolithic geography of Epirus. In Klithi: Palaeolithic Settlement and Quaternary Landscapes in Northwest Greece (Bailey G, ed.), pp 587-614. Cambridge, McDonald Institute for Archaeological Research.

USGS (2000). Surficial geology of Africa (downloadable data). http://certmapper.cr.usgs.gov/data/we/ ofr97470a/spatial/export/geo7_2age.zip (accessed February 1, 2012).

-Warren Y (2008). Crop-raiding baboons (Papio anubis) and defensive farmers: a West African perspective. West African Journal of Applied Ecology 14: 1-11.

-Warren Y, Higham JP, Maclarnon AM, Ross C (2011). Crop-raiding and commensalism in olive baboons: the costs and benefits of living with humans. In Primates of Gashaka: Socioecology and Conservation in Nigeria's Biodiversity Hotspot (Sommer V, Ross C, eds.), pp 307-332. New York, Springer.

Western D (2007). A half a century of habitat change in Amboseli National Park, Kenya. African Journal of Ecology 45: 302-310.

White $\mathrm{F}$ (1983). The Vegetation of Africa: A Descriptive Memoir to Accompany the Unesco/AETFAT/UNSO Vegetation Map of Africa. Paris, UNESCO.

Winder IC (2012). Hominin Landscapes and Co-Evolutionary Ecology: Accommodating Logical Incoherence and Complexity. PhD thesis, University of York.

Zinner D, Groeneveld L, Keller C, Roos C (2009). Mitochondrial phylogeography of baboons (Papio spp.) - indication for introgressive hybridization? BMC Evolutionary Biology 9: 83.

Zinner D, Pelaez F, Torkler F (2001). Distribution and habitat associations of baboons (Papio hamadryas) in Central Eritrea. International Journal of Primatology 22: 397-413.

Zinner D, Wertheimer J, Liedigk R, Groeneveld LF, Roos C (2013). Baboon phylogeny as inferred from complete mitochondrial genomes. American Journal of Physical Anthropology 150: 133-140. 